OPEN ACCESS

Edited by:

Irina Burd,

Johns Hopkins University,

United States

Reviewed by:

Ramkumar Menon,

University of Texas Medical Branch at Galveston, United States

Kenneth Beaman,

Rosalind Franklin University of Medicine and Science, United States

${ }^{\star}$ Correspondence: Kelycia B. Leimert kelycia@ualberta.ca

Specialty section: This article was submitted to Virus and Host,

a section of the journal

Frontiers in Cellular and Infection Microbiology

Received: 30 January 2021 Accepted: 30 June 2021 Published: 19 August 2021

Citation:

Leimert KB, Xu W, Princ MM

Chemtob $S$ and Olson DM (2021) Inflammatory Amplification: A Central Tenet of Uterine Transition for Labor. Front. Cell. Infect. Microbiol. 11:660983.

doi: 10.3389/fcimb.2021.660983

\section{Inflammatory Amplification: A Central Tenet of Uterine Transition for Labor}

\author{
Kelycia B. Leimert ${ }^{1 *}$, Wendy Xu ${ }^{1}$, Magdalena M. Princ ${ }^{1}$, Sylvain Chemtob ${ }^{2}$ \\ and David M. Olson ${ }^{1}$ \\ ${ }_{1}$ Department of Obstetrics and Gynecology, University of Alberta, Edmonton, AB, Canada, ${ }^{2}$ Department of Pediatrics, \\ Ophthalmology and Pharmacology, CHU Sainte-Justine Research Center, Montreal, QC, Canada
}

In preparation for delivery, the uterus transitions from actively maintaining quiescence during pregnancy to an active parturient state. This transition occurs as a result of the accumulation of pro-inflammatory signals which are amplified by positive feedback interactions involving paracrine and autocrine signaling at the level of each intrauterine cell and tissue. The amplification events occur in parallel until they reach a certain threshold, 'tipping the scale' and contributing to processes of uterine activation and functional progesterone withdrawal. The described signaling interactions all occur upstream from the presentation of clinical labor symptoms. In this review, we will: 1) describe the different physiological processes involved in uterine transition for each intrauterine tissue; 2) compare and contrast the current models of labor initiation; 3) introduce innovative models for measuring paracrine inflammatory interactions; and 4) discuss the therapeutic value in identifying and targeting key players in this crucial event for preterm birth.

Keywords: uterine transition, inflammation, amplification, parturition, preterm birth, cytokines, IL-1 $\beta$, IL-6

\section{INTRODUCTION}

The uterus is a dynamic organ that regularly undergoes cyclic changes and irregularly experiences considerable change in form and function. Throughout both the reproductive cycle and pregnancy, uterine modifications in cell proliferation, vascularization, and secretory outputs are induced by ovarian steroid hormones $17 \beta$-estradiol and progesterone to support menstruation, implantation, and decidualization (Bulletti et al., 1998; Gellersen and Brosens, 2003). The pregnant uterus increases more than 15 -fold in size over the 40 -week period of gestation to accommodate the growing fetus while actively maintaining a relaxed or quiescent state (Young, 2007). Then, as term approaches, the uterus must undergo extensive transition over a period of days into an active and contractile organ capable of performing the physiology of delivery. The process of uterine involution begins soon after birth and results in a return to the original uterine size and non-pregnant cycling state. Despite decades of obstetric research, progress in diagnosing risk for preterm birth and developing effective treatments has been disappointing, due in part to a lack of understanding of the physiology of birth and labor initiation. Therefore, although the uterus experiences considerable physiological and phenotypic change, the focus of this review article is on the extensive modification from the state of pregnancy to the state of labor or delivery. We call the sum total of genetic, cellular, 
and physiological changes that the uterus (and all maternal and fetal intrauterine tissues) must undergo during this period, uterine transition.

The question derives, how does a change as pervasive as pregnancy to parturition take place over such a short duration of time? The answer is amplification of the pro-inflammatory signals that activate the uterus for labor. These mediators are amplified through positive feedback interactions and cooperativity between ligands, cells, and tissues. A fundamental tenet of human physiology is the homeostatic balance in the body's internal environment; the principle of negative feedback prevents uncontrolled increases of chemical and nervous signals. Consequently, uninhibited positive feedback interactions are predominantly observed in deregulated disease states, such as tumor growth in cancer (Singer et al., 2000; Menssen et al., 2012; Benesch et al., 2015), autoimmune/autoinflammatory diseases (Beutler, 2009), and cellular senescence (Kandhaya-Pillai et al., 2017). Parturition uniquely forces the deviation of uterine physiology from normal homeostasis to ensure delivery, as maintenance of pregnancy past term compromises the health and ongoing viability of the mother and her fetus(es). Positive feedback mechanisms are not uncommon in reproductive and perinatal physiology. For instance, during ovulation estrogen drives the feedforward upregulation of gonadotropin-releasing hormone, which stimulates a surge in luteinizing hormone that results in the release of the mature oocyte (Holesh et al., 2021). Positive feedback or feedforward mechanisms achieve appropriate amplification to facilitate change at the cellular and tissue level over a short time period. The inflammatory system is an integral part of this upregulation process.

\section{BIRTH IS AN INFLAMMATORY EVENT}

Many studies have established the role of inflammatory processes in both term and preterm birth. Human microarray studies demonstrate that the transition to labor is an inflammatory event not limited to a single gestational tissue (Haddad et al., 2006; Bollapragada et al., 2009; Mittal et al., 2010; Stephen et al., 2015; Migale et al., 2016; Sharp et al., 2016; Lui et al., 2018). In the myometrium, 471 genes were differentially expressed in preparation for term labor and $86 \%$ of the altered pathways were identified as inflammatory in nature (Mittal et al., 2010). Dominant gene changes in term laboring myometrium and cervix are involved in leukocyte movement, intercellular communication and cytokine signaling (Bollapragada et al., 2009). In another study, 1761 genes in the myometrium increased or decreased in preparation for term labor; a meta-analysis of publicly available transcriptomic data confirmed that laboring myometrium downregulated muscle-specific processes while upregulating inflammatory processes (Sharp et al., 2016). In the choriodecidua, 796 genes increase or decrease in expression for term labor, with the activation of inflammatory or immune pathways leading the modifications to the transcriptome (Stephen et al., 2015). Moreover, six master regulators of transcriptomic changes for labor were identified by Ingenuity Pathway Analysis in choriodecidua and myometrium. Although the master regulators were different in choriodecidua from myometrium, downstream gene networks were similar and predominantly involved in inflammation (Lui et al., 2018). Amnion 'activated' for labor, characterized by high $\mathrm{NF \kappa B}$ activity, exhibited an increase in the expression of 919 genes including pro-contractile and proinflammatory targets compared to non-activated amnion (Lim et al., 2012). Genes involved in neutrophil and monocyte recruitment were upregulated in term fetal membranes with labor, yet inflammatory gene expression in peripheral blood did not change (Haddad et al., 2006). Together, these studies affirm that uterine transition is a localized intrauterine inflammatory response.

In the majority of cases the inflammatory events of parturition occur without an infectious process (i.e. no indication of bacterial, viral or parasite invasion), termed sterile inflammation (Elliott et al., 2001; Romero et al., 2014; Nadeau-Vallée et al., 2016). In a study by Romero et al. (2014), the concentration of interleukin (IL)-6 in amniotic fluid was collected by amniocentesis and measured by immunoassay in a population of women who delivered preterm; the authors selected a concentration of IL- $6 \geq 2.6 \mathrm{ng} / \mathrm{mL}$ as the index for sterile intra-amniotic inflammation. When microbial footprints were identified in addition to IL- $6 \geq 2.6 \mathrm{ng} / \mathrm{mL}$ in amniotic fluid, cases were classified instead as microbial-associated intra-amniotic inflammation or infection. Inflammation was present in higher frequencies in deliveries at earlier gestational ages; $85 \%$ of women who delivered early preterm ( $<30$ weeks of gestation) had intraamniotic inflammation, with $60 \%$ experiencing sterile inflammation and $25 \%$ infection. When considering all women who delivered before 37 weeks of gestation, $26 \%$ experienced sterile inflammation and $11 \%$ infection. However, the group of women who did not show an indication for intra-uterine inflammation by these criteria had a mean time span of 4 weeks between the date of their amniocentesis and delivery (Romero et al., 2014). This is noteworthy as inflammatory amplification can occur rapidly over a period of days to weeks, so it is likely that the number of women experiencing sterile intra-amniotic inflammation may have been higher than these numbers demonstrate. A recent study combined untargeted mass spectrometry, proteomic technology, and singlecell mass cytometry immunoassay approaches to assess integrated trajectories in serial blood samples collected over the last 100 days of pregnancy. The authors identified a distinct molecular shift that occurred 2-4 weeks before delivery where pregnancy maintenance transitioned to pre-labor biology. The molecular shift involved metabolomic, proteomic, and immunologic systems and occurred with similar accuracy in both term and preterm women (Stelzer et al., 2021).

In an infectious condition, the innate immune system is stimulated by pathogen-associated molecular patterns (PAMPs) produced by microorganisms. Amid a state of sterile inflammation, damage-associated molecular patterns (DAMPs) are produced in response to cellular stress, necrosis, and senescence. DAMPs are released by the increasingly physiologically stressed uterus, maturing fetus, and ageing placenta as parturition nears (Romero et al., 2014; Nadeau-Vallée et al., 2016). Fetal membrane senescence has been proposed as a fetal signal with an important role in labor initiation (Behnia et al., 2015). Senescent cells change their phenotype to a pro-inflammatory senescence-associated secretory 
phenotype but do not die, allowing for the continued release of markers of sterile inflammation that can drive positive feedback pathways involved in inflammation and senescence (Behnia et al., 2015). Both PAMPs and DAMPs activate toll-like receptors (TLRs), which induce inflammasome assembly, stimulation of proinflammatory cytokines and chemokines, and leukocyte activation, promoting the upregulation of uterine activation proteins (UAPs), prostaglandins, and their receptors (Cook et al., 2000; Cook et al., 2003; Ishiguro et al., 2016). Regardless of whether the initial stimulus is sterile (DAMP) or infectious (PAMP), a similar cascade of signaling events is involved, as depicted in Figure 1. The birth cascade is analogous to an iceberg - only a small fragment of the total picture is 'visible' at one time as the majority of upstream signaling processes are silent. By the time a woman presents with clinical symptoms of labor, considerable amplification has already taken place in the preceding days between upstream mediators. At this point, the birth cascade is nearly impossible to stop, similar to trying to intercept a train already travelling down the tracks at top speeds by standing on the tracks (Olson et al., 2008). This is why, despite substantial efforts, tocolytics have largely failed to inhibit preterm uterine contractions.

\section{HORMONAL REGULATION OF PREGNANCY}

Unfortunately, a model organism that precisely depicts the physiology of human parturition does not exist. In addition to discrepancies in the type of placentation, gestational length, and number of offspring, considerable physiological differences exist in the hormonal control of parturition and labor initiation. Progesterone is a potent relaxant that inhibits uterine contraction during pregnancy, described as the 'progesterone block' theory by Csapo in 1956 (Csapo, 1956). In most animal species, labor occurs following the systemic withdrawal of progesterone (Murr et al., 1974; Sanyal, 1978; Mitchell and Taggart, 2009). Humans are fairly unique in that systemic levels of progesterone continue to rise throughout pregnancy and do not decrease until after the delivery of both fetus and placenta.

Birth timing in the non-human primate and guinea pig is independent of systemic progesterone withdrawal, hence these two animal models remain the most physiologically representative of pregnant women. However, non-human primates are a complex and expensive model requiring a large and experienced team, making them feasible at only a few centers in the world. The guinea pig model is more cost effective and pregnancy is maintained by placental progesterone production with a lutealplacental shift similar to humans. The review by Mitchell and Taggart describes the physiological mechanisms of parturition in each animal model in considerable detail (Mitchell and Taggart, 2009).

Even though progesterone withdrawal does not act as the 'trigger' for human labor, progesterone still has an essential role in the termination of pregnancy. RU-486 is a competitive progesterone antagonist which is able to induce birth at any point in gestation in every species including in women, conveying that pregnancy cannot continue in the absence of progesterone (Csapo, 1956; Frydman et al., 1988; Avrech et al., 1991; Dudley et al., 1996; Fang et al., 1997). Over the past two decades a model of functional progesterone withdrawal has emerged, demonstrating that in spite of an increase in serum progesterone levels, its effect upon pregnancy maintenance in women decreases before delivery (Mesiano et al., 2002). Research is still ongoing, but one possible mechanism is that transcription of the human nuclear progesterone receptor $(n P R)$ gene is controlled by 2 different promoters, resulting in two $\mathrm{nPR}$ isoforms with different cellular and genomic actions: PR-A and PR-B (Kastner et al., 1990; Sartorius et al., 1994; Leonhardt et al., 2003). While PR-B promotes pro-gestational and antiinflammatory transcription, PR-A inhibits PR-B activity as well as modulating its own pro-labor genomic actions (Tan et al., 2012; Nadeem et al., 2017; Peters et al., 2017). During pregnancy, ratios of PR-A to PR-B expression are low ( 0.5). With advancing labor there is a shift in PR-A:PR-B nPR dominance and PR-A:PR-B ratios are much higher ( 3) (Merlino et al., 2007). This balance in receptor isoforms also involves inflammation. Myometrial cells manipulated to express a low $(\sim 0.5)$ PR-A:PR-B ratio representative of levels during pregnancy exhibited the decreased expression of inflammatory mediators, whereas cells with a high $(\sim 3)$ PR-A:PR-B ratio demonstrated increased pro-inflammatory expression levels (Tan et al., 2012). Fetal membranes do not express nuclear progesterone receptors, but do express progesterone receptor membrane component 1 and 2 (PGRMC1 and PGRMC2) (Merlino et al., 2009; Lozovyy et al., 2021). In fetal membranes, PGRMC1 was found to be significantly lower in pPROM deliveries (Feng et al., 2014), PGRMC2 was significantly lower in both term labor and pPROM fetal membranes, and both were downregulated in vitro in response to oxidative stress (Lozovyy et al., 2021). Contrarily, another study found PGRMC2 to be significantly upregulated in choriodecidua at both term and preterm labor (Shankar et al., 2010). More research is needed to differentiate the specific roles of different progesterone receptor types in functional progesterone withdrawal in maternal and fetal intrauterine tissues.

\section{INFLAMMATORY AMPLIFICATION AND LABOR INITIATION}

It is not a new concept that a communication system involving steroid hormones, inflammatory processes, and paracrine interactions plays a key role in regulating human labor and parturition (Olson et al., 1995). In their 2009 review, Mitchell and Taggart introduced a concept defined as the "Modular Accumulation of Physiological Systems" (MAPS) (Mitchell and Taggart, 2009). MAPS depicts the amassing of a series of distinct events upregulated in parallel to induce human labor in lieu of a single stimulus. The accumulation of these events eventually reaches a 'critical mass' endpoint that results in parturition. More recently, concepts have been introduced by Talati et al. (2017) and Keelan (2018), termed "inflammatory load" and "inflammatory burden". These concepts describe a steady 


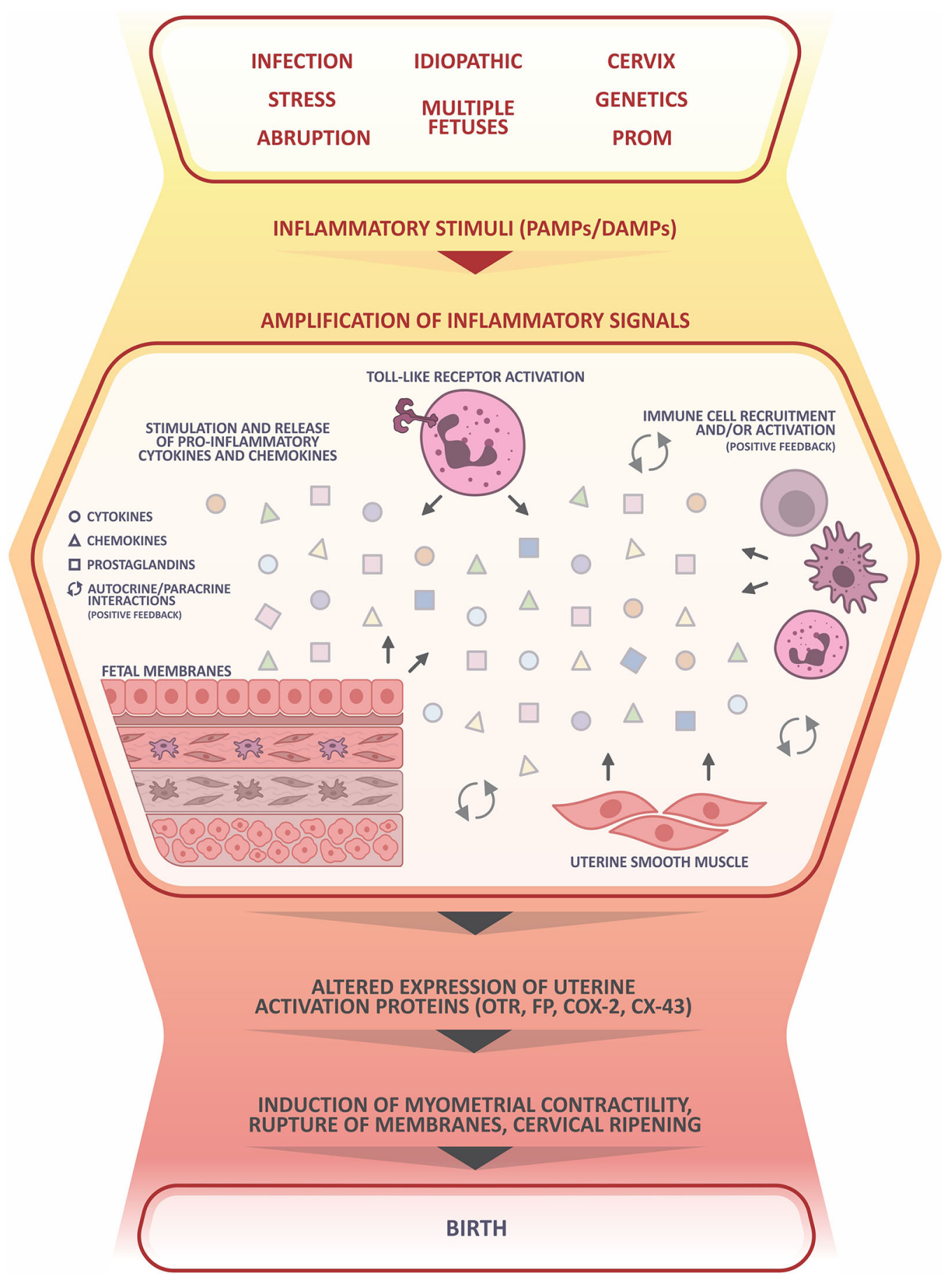

FIGURE 1 | Inflammatory roadmap leading to birth and preterm birth. PAMPs or DAMPs are stimulated by infection, stress, or other initiators. They activate toll-like receptors (TLRs), which, in turn induce inflammasome assembly and stimulation of pro-inflammatory cytokines and chemokines. These pro-inflammatory agents stimulate leukocyte activation so that they infiltrate the uterus and release more cytokines and chemokines, thereby recruiting and activating more leukocytes in a positive feedback loop. These mediators also act on adjacent intrauterine tissues; in response, those tissues release additional inflammatory mediators. The amplification of inflammatory signals promotes altered expression of uterine activation proteins including COX-2, CX-43, FP, and OTR, among many others. Together, these changes comprise the transition of the uterus of pregnancy into the active and contractile uterus of delivery, stimulating the physiological events of delivery. PROM, premature rupture of membranes; PAMP, pathogen-associated molecular pattern; DAMP, damage-associated molecular pattern; OTR, oxytocin receptor; FP, Prostaglandin $\mathrm{F}_{2 \alpha}$ receptor; COX-2, cyclooxygenase-2; CX-43, connexin 43. Portions of this figure were created using BioRender.com. 
increase in pro-inflammatory signal abundance over the gestational period. They hypothesize that human parturition occurs when pro-inflammatory mediators are upregulated and amplified until their signals exceed a threshold level that stimulates functional progesterone withdrawal and the other components required for the uterus to transition to its activated state for labor (Talati et al., 2017; Keelan, 2018). Hence human parturition is governed by localized paracrine interactions involving pro-inflammatory and pro-contractile systems. At term these intertwined systems drive amplification towards a critical and irreversible threshold level that becomes the trigger for human parturition.

As inflammation has a central role in all of the aforementioned mechanisms, there is value in investigating more specifically its role in the most commonly used in vivo parturition mouse models: spontaneous term labor (sTL), progesterone receptor antagonist RU486-induced preterm birth (PTB), and gram-negative endotoxin lipopolysaccharide (LPS)-induced PTB. Studies from two different research groups have compared gene or protein expression profiles in these three different models through labor and delivery. Both groups determined that while sTL and RU486PTB groups display similar profiles, the LPS-PTB mouse group profile is distinct (Shynlova et al., 2013; Migale et al., 2016). Shynlova et al. (2013) established the differences between groups by examining the expression of a series of inflammatory and uterine activation genes via RT-PCR, cytokine and chemokine outputs via multiplex analysis, and analyzing the populations of immune cells infiltrating into the myometrium. While expression levels in all three groups were similar postpartum, the LPS-PTB group differed before and at labor with a much more robust proinflammatory response and no measured increase in uterine activation protein (UAP) Connexin-43 (Shynlova et al., 2013). Migale et al. (2016) instead employed uterine temporal transcriptomics using multivariate modeling approaches to compare the three models. The principal component analysis identified that the LPS-PTB group demonstrated a divergent trajectory over time from the sTL and RU486-PTB groups. While changes to the transcriptome in sTL and RU486-PTB groups were $60 \%$ similar and did involve some degree of proinflammatory upregulation, $80 \%$ of the gene changes in the LPSPTB group were unique to that group alone and were predominantly involved in inflammation (Migale et al., 2016). Both research groups suggested that the RU486-PTB group was most similar to sTL as progesterone withdrawal is a fundamental component of labor initiation in mice, whereas inflammation may instead be involved in uterine remodeling postpartum and not labor initiation and delivery itself (Shynlova et al., 2013; Migale et al., 2016). Uterine remodeling postpartum or uterine involution is characterized by a reduction in the size and vascularization of the uterus so that it may return to a non-pregnant state of cycling.

These findings align with an earlier microarray study that compared uterine gene expression in spontaneous term delivery between mouse and human (Bethin et al., 2003). While genes involved in immune/inflammatory regulation, protease/protease inhibitors, and cell adhesion categories were downregulated for labor in the mouse uterus, they were instead upregulated in human myometrium, suggesting a lesser contribution of progesterone withdrawal and a more abundant contribution of inflammation in human parturition (Bethin et al., 2003). Other studies have supported that inflammation is not critical to mouse labor and delivery by demonstrating that depleting specific subsets of circulating immune cells such as neutrophils (Timmons and Mahendroo, 2006; Rinaldi et al., 2014), mast cells (Menzies et al., 2012), and total polymorphonuclear leukocytes (including neutrophils, eosinophils, and basophils) (Filipovich et al., 2015) had no effect on birth timing. Collectively, these data suggest that in mice there is an involvement of inflammatory processes in labor, but unlike progesterone withdrawal, these processes may be dispensable. However, a recent PTB mouse model demonstrated that inflammation can induce preterm delivery without a fall in systemic progesterone. The authors collected exosomes on day 18 of gestation and injected the exosomes into day 15 pregnant mice. The exosomes migrate into maternal cervix, myometrium, and fetal membranes and induced a localized inflammatory response via paracrine mechanisms that resulted in preterm delivery in $80 \%$ of mice, even while systemic progesterone levels remained constant (Sheller-Miller et al., 2019). Further research on labor initiation is needed, but it seems that parturition is a synchrony of multiple mechanisms and redundancy assures delivery in the absence of the other triggers.

The question going forward is, are inflammatory mediators in the human uterus relevant for only uterine involution or are they also relevant for uterine activation and expulsion? In the same study, Migale et al. (2016) then compared the gene profiles of the three mouse birth cohorts to human uterine transcriptome data collected before and after spontaneous term labor. Interestingly, of the three mouse cohorts, the gene profile of the human data set most closely paralleled the LPS-PTB model (Migale et al., 2016). Undoubtedly, the LPS-PTB model is not without its limitations, as it models systemic inflammation and not the localized intrauterine inflammation exhibited in human parturition. However, the comparison endorses the intrinsic role of inflammation in human parturition. A 2005 study used directed graphs of causal influence matched to a human RTPCR data set to statistically compare the likelihoods of different physiological scenarios for the initiation of human labor onset. The novel computational approach identified inflammatory processes as the predominant stimulus for human labor onset with high probability (Bisits et al., 2005). The Mesiano group has proposed tissue-level inflammation as a mechanism for the antagonism of progesterone-mediated gene changes that achieve functional progesterone withdrawal. IL-1 $\beta$ and prostaglandin $(\mathrm{PG}) \mathrm{F}_{2 \alpha}$, working through their receptors IL-1R and $\mathrm{FP}$, increase the $\mathrm{PR}-\mathrm{A} / \mathrm{PR}-\mathrm{B}$ ratio of progesterone receptor isoforms and increase the abundance and stability of PR-A (Madsen et al., 2004; Amini et al., 2016; Peters et al., 2017), thereby promoting pro-inflammatory expression and pro-labor transitioning (Tan et al., 2012). These findings emphasize a need for developing more representative methods for examining the molecular events of human parturition while expressing caution when interpreting findings from in vivo parturition animal models. 


\section{UTERINE TRANSITION INVOLVES MORE THAN JUST THE MYOMETRIUM}

To properly discuss the molecular changes involved in uterine transition and understand how paracrine signaling establishes localized changes for labor, the physiology of each uterine tissue must be considered separately and in cooperation with neighboring tissues. Within the pregnant uterus, signaling occurs between maternal and fetal gestational tissues. The coordination required to effect the five separate yet physiologically interrelated events of parturition: membrane rupture, cervical dilatation, myometrial contractility, placental separation and uterine involution (Olson et al., 1995), involves considerable tissue interactions.

\section{Myometrium}

The myometrium, or uterine smooth muscle, is predominantly comprised of fusiform-shaped cells. For the myometrium to contract as a coordinated unit during labor, electrical coupling between individual smooth muscle cells is essential. Ions and small molecules flow from cell to cell through gap junctions formed by groups of connexin proteins. These gap junctions allow intercellular communication and propagation of action potentials between smooth muscle cells, enabling contraction of a synchronized uterine musculature through excitationcontraction coupling (Garfield et al., 1977; Sims et al., 1982). Connexin proteins, such as Connexin (CX) 43, increase in expression at labor and are stimulated by rising levels of estrogens and progesterone via the PR-A receptor (Garfield et al., 1980; Chow and Lye, 1994; Di et al., 2001; Nadeem et al., 2017). In more than $80 \%$ of mice with a deletion of smooth muscle-specific $C x 43$, labor is delayed, likely due to the impaired electrical coupling of the myometrium (Döring et al., 2006). In addition to enhanced electrical signal transmission throughout the myometrium, the sensitivity of the uterus to contractile agonists is also increased at term. This development occurs as a result of the altered expression of a series of uterine activation proteins (UAPs), which change in expression for labor to increase systems of uterine contractility or suppress uterine relaxation (Cook et al., 2000). These markers of activation include connexins, cyclooxygenases, receptors and agonists of contractile stimulators, as presented in Table 1.

The shift in UAP expression profiles at labor is regulated by pro-inflammatory mediators, such as Interleukin- $1 \beta$ (IL-1 $\beta$ ) and IL-6. Many markers of uterine activation have binding sites for cytokine-induced transcription factors in their promoter regions. For example, FP's promoter region contains binding sites for both nuclear factor (NF) $\mathrm{BB}$ and NFIL-6, supporting more than one route for cytokine-mediated transcriptional regulation (Zaragoza et al., 2004; Zaragoza et al., 2006). In addition to FP, pro-inflammatory cytokines have been shown to regulate expression of COX-2 (Molnár et al., 1993; Kniss et al., 1997; Belt et al., 1999; Rauk and Chiao, 2000; Hirsch et al., 2006), OTR (Fang et al., 2000; Rauk and Friebe-Hoffmann, 2000; Schmid et al., 2001), CX-43 (Tonon and D'Andrea, 2000), ET-1 (Woods et al., 1999; Molet et al., 2000), iNOS (Marczin et al., 1993), PGs (Mitchell et al., 1990; Mitchell et al., 1991; Pollard et al., 1993), and NmUR2 (Nadeau-Vallée et al., 2016).

Steroid hormones estrogen and progesterone are also important regulators of UAPs. Progesterone acts through its PR-B receptor to suppress UAP expression through the modulation of transcriptional activity, such as antagonizing $\mathrm{NF \kappa B}$ via $\mathrm{NF \kappa B}$ inhibitor alpha (I $\mathrm{KB} \alpha$ ) (Loudon et al., 2003; Hardy et al., 2006). The pro-pregnancy actions of progesterone can be amplified by the activation of the cAMP pathway, which is also thought to play a role in maintaining uterine quiescence (Amini et al., 2019). In addition, progesterone represses OTR through direct binding of the receptor, subsequently preventing production of inositol phosphate and mobilization of calcium ions $\left(\mathrm{Ca}^{2+}\right)$ (Grazzini et al., 1998; Dunlap and Stormshak, 2004). Estrogen has the contrary effect, and promotes UAP expression via estrogen response elements in UAP promoter regions (Garfield et al., 1980; Soloff et al., 1983; Chibbar et al., 1995; Lefebvre et al., 1995; Di et al., 2001). Estrogen can also interact with OTR through extranuclear pathways to enhance myometrial contractility (Maiti et al., 2011; Welsh et al., 2012). Oxytocin stimulation, via OTR, induced activation of NFKB and upregulated gene expression of

TABLE 1 | Uterine activation proteins change their expression for labor ${ }^{\star}$.

\begin{tabular}{|c|c|c|c|}
\hline Uterine activation protein & Role & $\begin{array}{l}\text { Change for } \\
\text { labor }\end{array}$ & Key citations \\
\hline Cyclooxygenase 2 (COX-2) & $\begin{array}{l}\text { Enzyme catalyzing the rate limiting step in } \\
\text { prostaglandin synthesis }\end{array}$ & $\uparrow$ & $\begin{array}{l}\text { (Hirst et al., 1995; Slater et al., 1995; Mijovic et al., 1997; } \\
\text { Hirst et al., 1998; Cook et al., 2000) }\end{array}$ \\
\hline $\begin{array}{l}\text { Prostaglandin }(\mathrm{PG}) \mathrm{F}_{2 \alpha} \text { and } \\
\mathrm{PGF}_{2 \alpha} \text { receptor }(\mathrm{FP})\end{array}$ & $\begin{array}{l}\text { Uterotonic G-protein coupled receptor (GPCR) and } \\
\text { agonist }\end{array}$ & $\uparrow$ & $\begin{array}{l}\text { (Skinner and Challis, 1985; Romero et al., 1996; } \\
\text { Brodt-Eppley and Myatt, 1999; Cook et al., 2000; } \\
\text { Al-Matubsi et al., 2001) }\end{array}$ \\
\hline $\begin{array}{l}\text { Oxytocin (OT) and OT receptor } \\
\text { (OTR) }\end{array}$ & $\begin{array}{l}\text { Uterotonic G-protein coupled receptor (GPCR) and } \\
\text { agonist }\end{array}$ & $\uparrow$ & $\begin{array}{l}\text { (Fuchs et al., 1982; Fuchs et al., 1984; Chibbar et al., 1993; } \\
\text { Fang et al., 1996) }\end{array}$ \\
\hline Connexin $43(\mathrm{CX}-43)$ & $\begin{array}{l}\text { Gap junction protein essential for myometrial } \\
\text { connectivity }\end{array}$ & $\uparrow$ & (Garfield et al., 1977; Lye et al., 1993) \\
\hline $\begin{array}{l}\text { Endothelin } 1(E T-1) \text { and } E T-1 \\
\text { receptor } E T_{A}\end{array}$ & $\begin{array}{l}\text { Vasoconstrictor, uterotonic agonist and G-protein } \\
\text { coupled receptor (GPCR) }\end{array}$ & $\uparrow$ & $\begin{array}{l}\text { (Kozuka et al., 1989; Word et al., 1992; Yallampalli and } \\
\text { Garfield, 1994; Arthur et al., 2008) }\end{array}$ \\
\hline $\begin{array}{l}\text { Inducible nitric oxide synthase } \\
\text { (iNOS) }\end{array}$ & Enzyme catalyzing production of nitric oxide (NO) & $\downarrow$ & (Ali et al., 1997; Bansal et al., 1997) \\
\hline NmUR2 & Neuropeptide, uterotonic agonist & $\uparrow$ & (Nadeau-Vallée et al., 2016) \\
\hline
\end{tabular}

*This is just a small representation of hundreds of proteins that increase or decrease their expression in the process of uterine activation for labor. 
IL-6, IL-8, CCL5 and COX-2 in myometrial cells (Kim et al., 2015). UAPs can also be modulated by the stretching of the uterus to accommodate the growth and development of the fetus. The mechanical stretch of cultured human myometrial cells, amniocytes, fetal membranes, and decidua stimulates the induction of a series of pro-inflammatory cytokines and chemokines (Maehara et al., 1996; Loudon et al., 2004; KendalWright, 2007; Hua et al., 2012; Adams Waldorf et al., 2015; Lee et al., 2015), upregulates leukocyte recruitment (Lee et al., 2015) and upregulates COX-2 and OTR in myometrial cells (Sooranna et al., 2004; Terzidou et al., 2005). The inflation of an intrauterine balloon $(150 \mathrm{~mL})$ in the uterus of non-laboring women at term resulted in the increased synthesis of prostaglandins and labor induction (Manabe et al., 1982). Similarly, in non-human primates inflation of an intraamniotic balloon resulted in a spike in cytokine and prostaglandin release, followed by preterm delivery in 3 of the 6 animals (Adams Waldorf et al., 2015). Uterine stretch increased CX-43 and OTR in the rat (Ou et al., 1997; Ou et al., 1998), and OTR and COX-2 in the sheep (Wu et al., 1999).

\section{Cervix}

The cervix is the lower section or 'neck' of the uterus, and comprises columnar mucous-producing glandular epithelial cells, squamous epithelial cells, cervical fibroblasts and smooth muscle cells. However, the predominant composition of the cervix is importantly extracellular matrix, containing collagen, elastin, and glycoproteins. As the uterus grows and stretches during pregnancy to accommodate the growing fetus, the cervix has the important role of 'uterine gatekeeper,' maintaining rigidity despite increasing tension, pressure, and weight. The high collagen content of the cervix assists in this feat of physical integrity.

As birth approaches, the cervix must transition from closed and rigid to dilated and soft, stretching to accommodate the passage of the fetus through the birth canal. This transition occurs in two stages: cervical softening and ripening. Softening occurs gradually through gestation beginning near the end of the first trimester, whereas ripening is a more accelerated process occurring over the last days to weeks of pregnancy resulting in the loss of cervical integrity (Timmons et al., 2010). Collagen is remodeled by the re-organization of the matrix structure and through increasing levels of collagenases (Granström et al., 1992; Osmers et al., 1992; Shi et al., 1999). Glycosaminoglycans (GAGs) increase through pregnancy, rearranging collagen for increased cervical distensibility (Osmers et al., 1993). Mature collagen crosslink density decreases over the course of pregnancy (Yoshida et al., 2014), and collagen is degraded by increasing levels of collagenases and matrix metalloproteinases (MMPs), with only $30 \%$ of non-pregnant collagen levels remaining at term (Uldbjerg et al., 1983). Cervical ripening is influenced by steroid hormones, prostaglandins, growth factors and invading leukocytes (Stjernholm et al., 1996; Gu et al., 2012; Payne et al., 2012; Blesson et al., 2013; Kirby et al., 2016). First proposed to be an inflammatory process by Liggins in 1981, leukocytes and their products are involved in mediating changes to the cervical extracellular matrix (Junqueira et al., 1980; Liggins, 1981; Osmers et al., 1992; Sennström et al., 2000; Osman et al., 2003).

\section{Decidua}

The non-pregnant uterus is lined by endometrium, consisting of endometrial stromal cells, which differentiate into decidual cells through the process of decidualization. Once the blastocyst successfully implants, the decidua completely envelops the blastocyst and continues to grow and foster the invasion of trophoblasts and support placentation. Uterine natural killer cells, decidual macrophages, uterine dendritic cells, and regulatory $\mathrm{T}\left(\mathrm{T}_{\text {reg }}\right)$ cells are present in decidua and involved in vascular remodeling and adaptive immune roles suppressing anti-embryo maternal immune responses (Hanna et al., 2006; Seavey and Mosmann, 2008; Gomez-Lopez et al., 2010; Mori et al., 2016). The decidua is essential not only in the establishment of pregnancy, but to maintain and support pregnancy throughout gestation through the production of important hormones and growth factors.

As labor approaches, the physiology of the decidua changes. Like the myometrium, the decidua upregulates UAPs and undergoes activation. COX-2 is considerably elevated in the decidua in late gestation and labor which makes it a major producer of $\mathrm{PGF}_{2 \alpha}$ (Hirst et al., 1998), and uterotonic OTR and FP receptors are expressed in decidua (Okazaki et al., 1981; Fuchs et al., 1982). Decidual FP expression levels increase fourfold with labor, while expression of all progesterone receptor (PR) isoforms diminish (Goldman et al., 2005; Makino et al., 2007). In addition, pro-inflammatory mediators such as IL-6, CCL2, CCL4, CCL5, CXCL8, and CXCL10 are upregulated in the decidua at term and correlate with decidual leukocyte abundance (Osman et al., 2003; Hamilton et al., 2013; El-Azzamy et al., 2017). Leukocyte infiltration and activation in the decidua precedes term and preterm delivery in both human and rat (Hamilton et al., 2012; Xu et al., 2016). Ex vivo organ culture of decidua stimulated with $\mathrm{PGF}_{2 \alpha}$ upregulated expression of MMP2 and -9 , enzymes involved in the degradation of adjoining fetal membranes, while decreasing expression of the tissue inhibitor of metalloproteinases-1 (TIMP-1) (Ulug et al., 2001). The mechanical stretch of decidual cells increased activity of MMP-1 while also upregulating CXCL1 and CXCL8 mRNA and protein (Zhao et al., 2013).

\section{Fetal Tissues}

The human fetal membranes (hFM), consisting of chorion and amnion, envelope and protect the fetus throughout pregnancy. Chorionic trophoblasts invade the maternal decidua and form a highly integrated choriodecidua maternal-fetal interface (Mitchell and Powell, 1984). By mid-pregnancy, the fetal membranes line the entire uterine cavity. As the growing fetus kicks, stretches, and moves, the fetal membranes maintain viscoelasticity to withstand movements and avoid rupture, safely containing the fetus and surrounding amniotic fluid (Parry-Jones and Priya, 1976; Lavery and Miller, 1979; Patrick et al., 1982). This characteristic is modified in preparation for labor, as the membranes must then rupture to permit passage of the fetus through the birth canal. Membrane rupture is facilitated by biomechanical and biochemical changes weakening the amnion and chorion combined with the mechanical force of uterine 
contractions at labor (Kumar et al., 2011; Puthiyachirakkal et al., 2013). The amnion is the load-bearing structure in the fetal membranes; although the tissue is very thin, mechanical testing has demonstrated that it is stiffer, tougher and stronger than the chorion, and the strength of the amnion decreases significantly in preparation for labor (Helmig et al., 1993; Bircher et al., 2019). The amnion and chorion layers are connected by extracellular matrix with a high collagen content, this matrix must also undergo enzymatic breakdown during membrane rupture.

Increasing amounts of oxidative stress and cell senescence occur through the gestational period, prompting the release of sterile inflammatory mediators of parturition, including DAMPs and mediators of the senescence-associated secretory phenotype (SASP) (Menon et al., 2017). Fetal membranes overlaying the cervix have been shown to express less antioxidant enzyme activity than the surrounding areas of the membrane, making that zone more susceptible to oxidative stress, damage, and rupture (Chai et al., 2012). Fetal membrane senescence has been proposed to function as a biological clock, as senescence can drive inflammatory upregulation and contribute to birth timing and membrane rupture (Menon et al., 2016). The inflammasome, responsible for IL-1 $\beta$ production, is activated at term labor in both the fetal membranes and in choriodecidual leukocytes (Gomez-Lopez et al., 2017; Romero et al., 2018). Inflammatory mediators induce MMPs, which remodel extracellular matrix through the degradation of collagen. For example, in vitro stimulation of TNL fetal membrane explants with TNF $\alpha$ and IL- $1 \beta$ induced membrane weakening, apoptosis, and collagen remodeling, as well as the upregulation of MMP-9 and downregulation of TIMP-3 (Kumar et al., 2006). Thrombin directly induces weakening of the amnion membrane in vitro, whereas TNF $\alpha$ and IL- $1 \beta$ instead act indirectly on the amnion by stimulating the release of intermediates from the choriodecidua (Kumar et al., 2011; Puthiyachirakkal et al., 2013). MMP-2 and MMP-9 degrade collagen IV, a prominent collagen in the basement membrane of the amnion, in chorionic cytotrophoblasts and in connective tissue (Malak et al., 1993; McLaren et al., 2000).

\section{Maternal Leukocytes}

In preparation for labor, the human fetal membranes exhibit chemotactic properties, releasing chemoattractant that induces the migration of maternal peripheral leukocytes into intrauterine tissues (Gomez-Lopez et al., 2009; Gomez-Lopez et al., 2011; Takeda et al., 2017). Concurrently, the abundance of granulocytes, monocytes, and lymphocytes increase and circulating leukocytes become more responsive to chemoattractant by upregulating key receptors and intracellular signaling molecules (Yuan et al., 2009; Zhang et al., 2017; Lee et al., 2020). Pro-inflammatory cytokine and chemokine abundance in human intrauterine tissues and amniotic fluid increases at labor (Halgunset et al., 1994; Elliott et al., 2001; Osman et al., 2003), and leukocyte infiltration into myometrium (Thomson et al., 1999), decidua (Xu et al., 2015; Arenas-Hernandez et al., 2019), cervix (Bokström et al., 1997; Osman et al., 2003) and fetal membranes (Gomez-Lopez et al., 2009; Jacobs et al., 2021) has been characterized at term. Leukocyte extravasation into gestational tissues provides another level of feed-forward tissue-level inflammatory amplification as the leukocytes interact with surrounding cells, as demonstrated in Figure 1. Mediators released by the infiltrated leukocytes contribute to the transitional events described above such as membrane rupture and cervical ripening, as well as the preparation for tissue repair and remodeling after delivery (Gomez-Lopez et al., 2010).

\section{INFLAMMATORY COOPERATIVITY BETWEEN LIGANDS AND TISSUES}

Nearly all we know about parturition in humans is derived from in vitro studies examining each mediator in isolation or ex vivo studies in individual tissues. However, as described throughout this review, the in vivo environment is much more complex and paracrine interactions between cells and adjacent tissues are an important component of that complexity. We must pursue other avenues to investigate parturition biology and create useful models for collecting the crucial pre-clinical data needed to develop clinical products for women's pregnancy health. Studies in recent years have shown that there is a lot we can learn from studying ligands in combination and/or building more precise models to better mimic the in vivo situation.

For example, two of the most important mediators involved in the transcriptional regulation of IL- 6 are IL- $1 \beta$ and TNF $\alpha$, as both cytokines induce the transcription factors activator protein (AP)-1, nuclear factor (NF) KB, and NFIL-6 (Akira et al., 1990; Karin, 1995; Khanjani et al., 2011). These transcription factors can interact in complexes to cooperatively regulate IL-6 transcription. NFIL- 6 and NFKB together induced a synergistic 40-fold increase in IL-6, 20 times higher than their individual effects (Matsusaka et al., 1993). Collectively, AP-1, NFKB, and NFIL- 6 formed a transcription factor complex that resulted in a nearly 300 -fold increase in IL-6, much greater than the outcome of individual or paired combinations (Faggioli et al., 2004). In astrocytes, the transcription factors CREB, NFKB, and CBP form a complex that synergistically upregulates transcription of both IL-6 and COX-2 (Spooren et al., 2010). CCL2 synergizes with a series of different chemokines, including IL-8 and CXCL6, to induce amplified leukocyte chemotaxis (Gouwy et al., 2004; Gijsbers et al., 2005). This concept is not new to immunology, as amplification is employed to rapidly mobilize leukocytes in immune defense responses. The role of cooperative regulation must be investigated further as part of the signaling contributing to uterine transition, especially as many UAPs have binding sites in their promoter regions for several inflammatory transcription factors. In human myometrial cells, sequential combinations of IL- $1 \beta$ and PGF $_{2 \alpha}$ upregulated cytokine IL- 6 and UAP COX-2 to levels much higher than the sum of each mediator's individual effects (Leimert et al., 2019).

Likewise, scientific models must be designed to study interactions between adjacent cell and tissue types within the maternal-fetal interface. In recent years, a number of studies have demonstrated paracrine interactions through the development of different intrauterine co-culture models. Uterine myocytes cocultured with primary term non-laboring monocytes released much greater levels of IL- 6 and IL-8 than the output of each cell type individually. Furthermore, the myocyte-monocyte crosstalk 
also elevated uterine myocyte contractility (Rajagopal et al., 2015). In another study, myometrial cells stimulated with $\mathrm{CRH}$ and co-cultured with THP-1 monocytes upregulated higher outputs of $\mathrm{PGE}_{2}$, cytokines and chemokines, and UAP expression compared to myometrial cells cultured alone (You et al., 2014). In addition, myometrial cells co-cultured with differentiated macrophages upregulated myocyte contractility and CX-43 protein expression following LPS stimulation (Wendremaire et al., 2020). Lee et al. (2015) treated uterine endothelial cells with conditioned medium collected from cultures of uterine myocytes that had been stretched in vitro (Lee et al., 2015). As a result, the endothelial cells exhibited an upregulation in cell adhesion molecules on their cell surface. Moreover, leukocytes exposed to the myocyte-conditioned medium upregulated monocyte surface markers of activation, increased granulocyte binding to uterine endothelial cells, and upregulated transendothelial migration (Lee et al., 2015). A follow-up study demonstrated that even without stretch, conditioned medium collected from cultured primary term myometrial cells or primary term decidual cells induced an upregulation of activation markers involved in adhesion and migration in early pregnant peripheral leukocytes, supporting a role for paracrine interactions between cell types in inducing leukocyte extravasation into gestational tissues (Farine et al., 2017). To model the paracrine delivery of inflammatory signals from fetal to maternal tissues in vitro, exosomes were collected from primary amnion epithelial cells and administered to cultures of myometrial cells or primary decidual cells. Over 24 hours, exosomes entered the maternal cells and induced inflammatory upregulation, significantly increasing IL-6, IL-8, $\mathrm{PGE}_{2}$ and NFKB (Hadley et al., 2018).

Our group co-cultured primary uterine myocytes with fetal membrane tissue explants and found that 18 inflammatory mediators were synergistically upregulated when compared to the tissues cultured in isolation (Leimert et al., 2018). Interestingly, the cytokines and chemokines with the highest total concentration output or largest fold-change increase in this co-culture model resembled the lists of mediators identified as the most altered gene pathways in preparation for labor in the human microarray studies previously discussed (Haddad et al., 2006; Bollapragada et al., 2009; Mittal et al., 2010; Stephen et al., 2015), supporting the validity of this method in modeling proinflammatory amplification in uterine transition for labor. Keelan et al. (2009) developed an ex vivo model using an Ussing chamber that allows for the independent stimulation of the maternal (decidual) and fetal sides of the human fetal membranes. Using this model, it is possible to measure separate secretory outputs from each side as well as study the barrier and transfer functions of the tissue. The authors demonstrated that when the maternal decidual side is stimulated with LPS, cytokines are significantly upregulated on both the maternal and fetal sides, even though LPS does not pass through to the fetal compartment. The authors suggested that the inflammatory upregulation in the fetal compartment likely occurred due to a cascade of paracrine interactions taking place throughout the layers of the tissues (Keelan et al., 2009). More recently, this concept has been developed further. The fetal membrane organ-on-chip, a novel in vitro system, utilizes a multi-chamber microfluidic device to study interactions between fetal amnion epithelial cells and maternal decidual stromal cells with more control, higher sensitivity, and increased precision (Richardson et al., 2019). Further optimization has resulted in a microfluidic organ-onchip system of the feto-maternal interface, containing primary decidual, chorion, and amnion (mesenchyme and epithelial) cells. Using this system, the authors were able to model the propagation of ascending maternal infection and show cell type specific immune responses to the exposure. LPS treatment of decidual cells resulted in inflammatory upregulation in decidual cells within 24 hours, fetal chorion within 48 hours, and fetal amnion cells within 72 hours (Richardson et al., 2020). A cervical epithelial organ-on-chip system has also been recently developed, incorporating endocervical and ectocervical epithelial cells (Tantengco et al., 2021). These creative model systems offer alternative methodologies for research questions that may not be answered precisely with accessible animal models.

\section{KEY UPSTREAM MEDIATORS IN UTERINE TRANSITION}

Characterizing the central mediators within the proinflammatory network of uterine transition is of the utmost importance. Two mediators intrinsically involved in the tissuelevel transformation of maternal and fetal intrauterine tissues for labor are IL-1 $\beta$ and IL-6. IL-1 $\beta$ is a member of the IL- 1 cytokine family, generated following the activation of pattern recognition receptors such as TLRs and NOD-like receptors. IL-1 $\beta$ signals through a heterodimeric complex; the functional ligand binding chain IL-1R1 binds IL-1 and complexes with its accessory protein (IL-1RAcP or IL-1RAcPb) to stimulate a downstream cascade that results in the activation of transcription factors AP-1 and NFKB. IL-1 is a potent cytokine, able to induce sizable biological responses at low concentrations. A maximum cellular response to IL-1 occurs at only $1 \%$ occupancy of the IL-1R1 receptors (Dower and Sims, 1990). IL-1 activity must therefore be highly regulated through negative feedback; the endogenous IL-1R antagonist (IL-1ra) competes with IL-1 ligand to bind and sequester IL-1R1 (Seckinger et al., 1987). High levels of IL-1ra in both secretory and intracellular forms are expressed endogenously; bioavailability of IL-1ra ligand is typically several thousand times higher than IL-1 ligand (Arend, 1993). The second IL-1 receptor, IL-1R2, also binds IL-1 ligand and IL-1RAcP but is lacking a TIR domain, thereby scavenging IL-1 and functioning as a decoy receptor without the production of signal transduction (Boraschi and Tagliabue, 2013). In addition to IL-1R2, soluble forms of IL1R1 and IL-1RAcP also exist as decoy receptors to sequester IL-1 ligand without signal transduction or cellular response.

At term labor, IL-1 $\beta$ is upregulated in amniotic fluid (Romero et al., 1990; Romero et al., 1992) and intrauterine tissues including myometrium, decidua, cervix and fetal membranes (Ammälä et al., 1997; Elliott et al., 2001; Osman et al., 2003). The endogenous 
antagonist IL-1ra decreases in cervicovaginal fluid at spontaneous term labor onset (Heng et al., 2014). IL-1 $\beta$ has an influential coordinating role in the regulation of pro-inflammatory and prolabor genes in intrauterine tissues. In decidual cells, microarray data presented a significant upregulation of 350 transcripts and the activation of an estimated 57 transcription factors following IL-1 $\beta$ stimulation (Ibrahim et al., 2016). A short exposure to IL-1 $\beta$ upregulates 98 inflammatory genes in PHM1-41 uterine myocytes by at least 3-fold, including COX-2 (7.9-fold), NFKB (10.9-fold) and genes involved in extracellular matrix (ECM) remodeling, cell adhesion and angiogenesis (Chevillard et al., 2007).

IL- $1 \beta$ is a potent stimulator of prostaglandin synthesis in all gestational tissues via COX-2 induction (Romero et al., 1989; Brown et al., 1998; Bartlett et al., 1999; Rauk and Chiao, 2000; Ibrahim et al., 2016), and contributes to functional progesterone withdrawal by increasing the stability and abundance of the PRA receptor (Amini et al., 2016; Peters et al., 2017). The excitability of primary human myometrial cells is upregulated by $\mathrm{IL}-1 \beta$, increasing both basal calcium entry and spontaneous calcium transients (Tribe et al., 2003). RU486-induced rat deliveries demonstrated increased uterine expression of IL-1R1, IL-1R accessory proteins AcP and $\mathrm{AcPb}$, and decreased expression of decoy receptor IL-1R2 (Ishiguro et al., 2016). Mice administered an intrauterine injection of IL-1 $\beta$ exhibited a significant increase in mRNA abundance of genes encoding for COX-2, FP, OTR, CX-43, MMP-1, 3, 9, IL-1 $\beta$, IL-6, IL-8, CCL2 and IL-1R1 in the myometrium compared to vehicleinjected animals (Nadeau-Vallée et al., 2015). Human myometrial cells stimulated with IL-1 $\beta$ also upregulate mRNA abundance of the IL-1 receptors and accessory proteins (Leimert et al., 2019), further contributing to inflammatory amplification by minimizing negative regulation of IL-1 $\beta$. It is therefore not surprising that IL- $1 \beta$ injection effectively induces preterm birth in a range of animal models, such as the mouse (Romero et al., 1991; Yoshimura and Hirsch, 2005; Nadeau-Vallee et al., 2015), the rabbit (in combination with TNF $\alpha$ ) (Bry and Hallman, 1993), and the nonhuman primate (Sadowsky et al., 2006).

One of the key mediators stimulated by IL-1 $\beta$ is IL-6, a cytokine involved in a wide range of biological functions, including implantation, pregnancy, and parturition. IL-6 is produced in abundance by the myometrium, cervix, and choriodecidua before and during labor (Osman et al., 2003), and elevated or deficient IL-6 levels are associated with infertility, fetal loss, and other pregnancy disorders (Prins et al., 2012). IL-6 is measured in amniotic fluid in low concentrations beginning in the second trimester, but at term, concentrations of IL-6 increase from 399 to $4800 \mathrm{pg} / \mathrm{mL}$ with labor onset (Opsjłn et al., 1993). Human amnion and decidual cells stimulated by physiological concentrations of IL-6 (as measured in amniotic fluid at term) upregulate the production of prostaglandins (Mitchell et al., 1991). In the rat, IL-6 increases expression of uterotonic receptor OTR in the uterus (Fang et al., 2000). Mice with a null mutation for Il6 (Il6-/-) deliver 24 hours later than mice with an IL-6 presence due to a 24-hour delay in the upregulation of UAPs, and normal birth timing can be restored with exogenous IL-6 administration (Robertson et al., 2010). However, although Il6-/- mice deliver late and IL-6 levels are upregulated in LPS- induced preterm birth mouse models (Nadeau-Vallée et al., 2015), IL-6 injection alone is not sufficient to induce preterm labor (Yoshimura and Hirsch, 2003) and IL-6 does not stimulate uterine contractions (Dajani et al., 1994). Nonetheless, IL-6 has been pursued as a diagnostic marker for preterm birth. Women who experienced spontaneous preterm births before 35 weeks had significantly elevated IL-6 levels in amniotic fluid in second trimester (Wenstrom et al., 1998) and in cervical fluid at 24 weeks of gestation (Goepfert et al., 2001). In addition, Robertson's group demonstrated the importance of IL-6 in mediating $\mathrm{T}$-cell population changes in late pregnancy in the mouse using an Il6-/- model. IL- 6 mediates $\mathrm{CD}^{+} \mathrm{T}$ cell differentiation into Th17 cells and $\mathrm{CD}^{+} \mathrm{T}$ cell differentiation into Foxp $3^{+} \mathrm{T}$ regulatory cells, while decreasing the number of decidual Th9 cells (Gomez-Lopez et al., 2016). These IL-6mediated $\mathrm{T}$-cell population changes contribute to the progression of parturition. Exogenous IL- 6 administration restored $\mathrm{T}$ cell populations by $60 \%$ and recovered birth timing (Gomez-Lopez et al., 2016).

\section{INFLAMMATORY AMPLIFICATION PROPELS THE GEARS}

Evolution seems to have prepared humans for the contractile events of labor and the immune effects of giving birth within a single interlaced system. The MAPS (Mitchell and Taggart, 2009), inflammatory load (Talati et al., 2017), and inflammatory burden (Keelan, 2018) concepts feature many parallels, essentially illustrating a single unified theory with different terminology. Instead of an individual trigger initiating birth, what we instead see are a series of increasing interactions involving both contractile and immune pathways. We propose that pro-inflammatory amplification propelled by cooperative interactions between ligands, cells, and tissues presented in this review is an intrinsic part of this accumulative process, driving the increase in inflammatory load or burden in late gestation until reaching that critical mass endpoint resulting in functional progesterone withdrawal and labor induction. Our conceptual framework in Figure 2 incorporates parts of each of these concepts while focusing in on the paracrine interactions driving inflammatory amplification.

One could depict the processes of human labor as being synonymous with a series of small gears together turning one large wheel. The small components begin to move and then pick up speed, moving more quickly as upregulation continues to be amplified through intrinsic and extrinsic inflammatory interplay. Both fetal membrane senescence and uterine stretch contribute to this escalating pro-inflammatory profile. As these gears turn, their motion affects neighboring gears and initiates movement in the next grouping of wheels. This interaction represents synergy between adjacent tissues. As layer upon layer of gears turn, the speed increases and it becomes more and more difficult to stop the momentum. The cooperativity and amplification depicted in this analogy reveals why we continue to fail at preventing preterm birth in humans, even when we succeed in animal 
models. This is not a sequence of events, but a series of parallel events occurring concurrently and gradually accumulating over time. We must slow the motion of this wheel before it reaches 'the point of no return' and its momentum becomes too strong to suppress. Tocolytic therapies target a wheel already rotating at top speeds and attempt to slow it down, resulting in temporary delay (or no delay at all) until other parallel pathways compensate for the one that is suppressed.

\section{CHANGING THE PTB TREATMENT PARADIGM}

Preterm birth (PTB), defined as birth before the $37^{\text {th }}$ completed week of gestation, affects $5-18 \%$ of births in 184 countries worldwide resulting in 15 million babies born preterm each year (March of Dimes et al., 2012). Of those, 1.1 million do not survive (Blencowe et al., 2012; March of Dimes et al., 2012).
Those who do survive may face a spectrum of lifelong disabilities, including cerebral palsy, intellectual impairment, chronic lung disease, vision and hearing loss (Committee on Understanding Premature Birth and Assuring Healthy Outcomes, 2007). Globally, PTB complications are the leading cause of newborn death and the second greatest cause of death in children (March of Dimes et al., 2012). In spite of all of the medical advancements of the era and the increasing success of neonatologists in saving babies born at earlier and earlier gestational dates, we still do not have an effective method of prevention for this global problem. Although we have seen progress in survival rates of preterm infants, no intervention advancements have been made, resulting in escalating healthcare costs (Olson et al., 2008).

The strategic approaches for treating PTB have changed over time. Forty years ago, the strategy was to try to completely stop PTB by antagonizing contractile mediators that stimulated myometrial contractions. Drugs in this category included betaadrenergic agonists, calcium channel blockers or competitors,
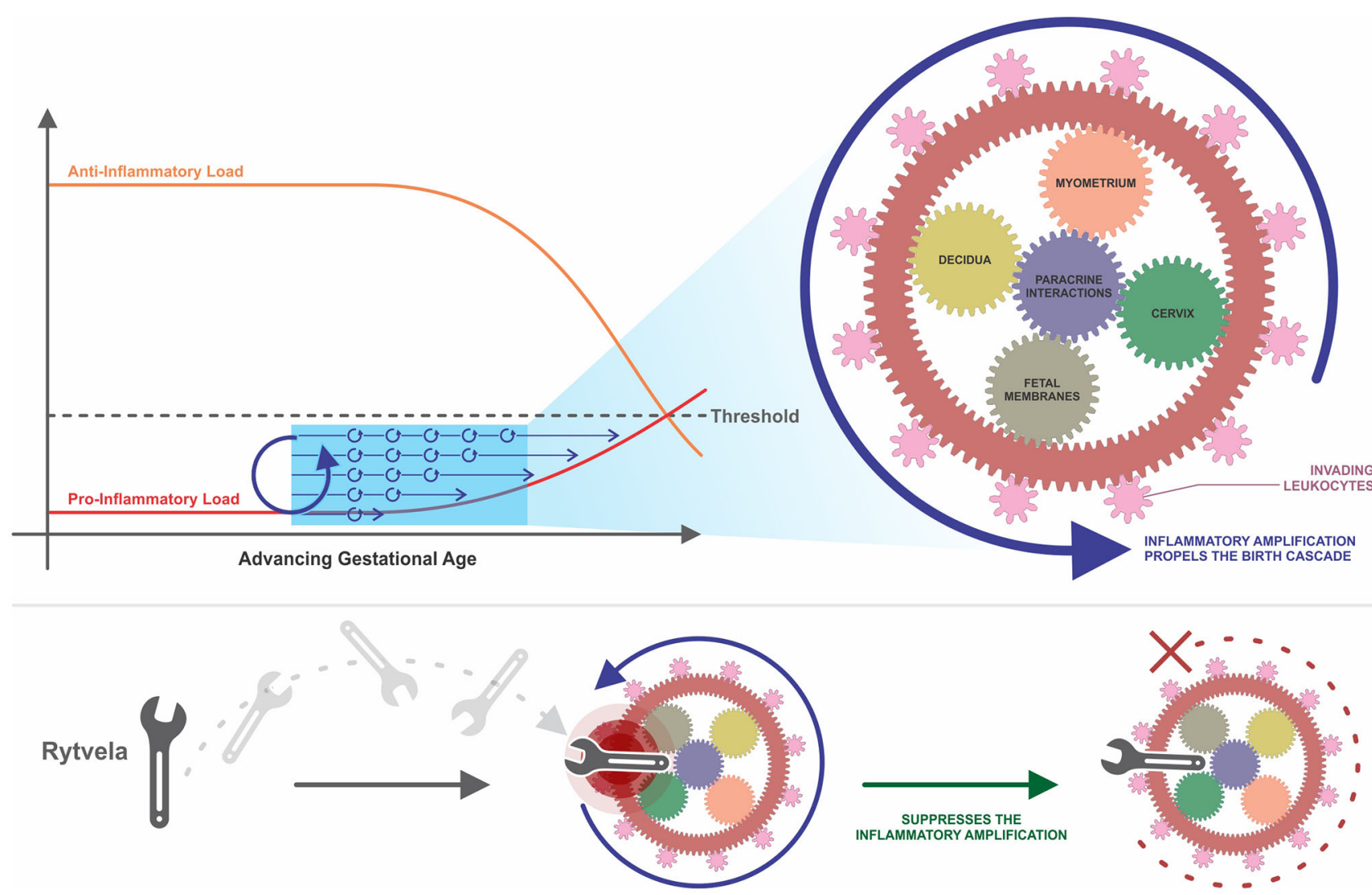

FIGURE 2 | A conceptual framework of uterine transition. This framework incorporates the concepts of MAPS and anti- and pro-inflammatory load introduced by Mitchell and Taggart, (2009), Talati et al. (2017), and Keelan (2018). Parallel up-regulatory events accumulate over time, driven by paracrine interactions between various cells and tissues in the intrauterine environment. Amplification occurs within and between these pathways, which begins to propel the momentum of the larger wheel. The pro-inflammatory load continues to build while the anti-inflammatory load, such as the progesterone blockade, diminishes. These two loads ultimately approach each other, creating a threshold value that once crossed, triggers irreversible labor and parturition at term or preterm. Once labor is established, the gearwheel is moving with an inertia too powerful to be stopped with existing tocolytic therapies. An efficacious anti-inflammatory intervention, such as rytvela, is essentially a spanner in the works that suppresses the upstream process of inflammatory amplification and thereby slows the turning of the wheel before it reaches top speed. MAPS, modular accumulation of physiological systems; rytvela, IL-1R allosteric antagonist. 
oxytocin receptor antagonists or prostaglandin synthesis inhibitors (Olson et al., 2008). None of these were very effective as the primary endpoints were to stop contractions with the anticipation the pregnancy would then continue to term. However, this approach failed to consider that the underlying mechanism driving uterine contractions, the fact that the uterus was already activated for labour and therefore unable to revert back to its pre-activation, pregnant state, was not considered. This is why these drugs failed. A modern variation on this concept is that while contractions cannot be permanently stopped, they can be suspended for up to five days. With a 48 hour window, synthetic glucocorticoids can be administered to the mother with enough time to permit them to increase fetal lung surfactant synthesis and release to reduce the incidence or severity of respiratory distress syndrome. This is the strategy employed by ObsEva and its product OBE022, a competitive $\mathrm{PGF}_{2 \alpha}$ receptor antagonist, which in combination with atosiban diminished delivery at 48 hours 55\% more effectively than atosiban alone (www.obseva.com/obe022/). A third contemporary strategy is to intervene farther upstream in the birth cascade at a point that occurs prior to uterine activation in order to prevent the physiological change in the uterus from a pregnant to a parturient state. This is the strategy behind inflammatory antagonists such as rytvela, BSCIs or naloxone.

As it has become clearer that inflammation plays a central role in the delivery process, PTB researchers have turned their attention to the possibility of anti-inflammatory therapies. As the earliest event of the inflammatory birth cascade is the activation of TLRs by DAMPs or PAMPs, the inhibition of specific TLRs has been pursued as a target to suppress amplification. Wildtype mice treated with (+)-naloxone, a TLR4 antagonist, and Tlr4null mice (Tlr4-/-) both deliver late due to delayed inflammatory upregulation and UAP induction (Wahid et al. 2015). In mouse models of PTB induced by LPS or E.coli, (+)-naloxone successfully delayed PTB, improved birth weights, and reduced the incidence of postnatal death (Chin et al., 2016). Another compound targeting upstream, the broad-spectrum chemokine inhibitor, BSCI, binds the type 2 somatostatin receptor. Inhibition of the type 2 somatostatin receptor results in suppression of a series of chemokines, but the exact mechanism of how BSCI acts on chemokines remains unknown. BSCI delayed LPS-induced PTB in mice and decreased uterine inflammatory expression (Shynlova et al., 2014). In a non-human primate model of Group B Streptococcus-induced PTB, BSCI effectively blocked myometrial contractility and preterm labor, but increased microbial invasion of the amniotic cavity resulting in more severe fetal inflammation and injury (Coleman et al., 2020). These compounds must be further explored, as the broader the inhibition, the greater the potential risk for possible unintended adverse consequences for mother and child. Inhibition of these targets could also possibly suppress important components of the maternal innate immune system, the body's first line of defense against foreign pathogens.

Uterine inflammatory amplification comprises different tissue and cell types which, amongst other mediators, involves cytokines IL-1 $\beta$ and IL-6. IL-1 $\beta$ and IL- 6 are positioned below
TLRs on the birth cascade, but still upstream from current tocolytics. Due to the extent of paracrine interaction between these pathways, suppression of certain actions of IL- $1 \beta$ or IL- 6 may be sufficient to suppress amplification before reaching the 'critical mass' endpoint or 'inflammatory load threshold.' An optimal therapeutic candidate for preterm birth would inhibit both pro-inflammatory and pro-contractile systems. IL-1 $\beta$ and IL- 6 represent points of convergence of these systems in the parturition process. One of the controversial issues regarding administration of tocolytics is their use when maternal inflammation or possibly infection is present. In this situation is it better for the fetus to be delivered or not? Some insight can be derived from mouse studies where pro-inflammatory agents (IL-1 $\beta$, LPS, LTA) were used to stimulate maternal inflammation and preterm labor. Rytvela or 101.10, an IL-1R1 allosteric modulator, decreased the levels of maternal cytokines, blocked the preterm delivery and protected the fetuses from inflammatory harm more effectively than IL-1R antagonist Kineret (NadeauVallée et al., 2015; Nadeau-Vallée et al., 2017). Instead of blocking all signaling from the IL-1R1 receptor like the actions of orthosteric antagonist Kineret, Rytvela is highly specific and selective. Rytvela suppresses signaling through the JNK/AP-1 pathway without abolishing $\mathrm{NFKB}$ signaling involved in cytoprotection and immune vigilance. Inflammatory pathways can provoke harmful effects when overexpressed, but they are also involved in crucial signaling that is essential for normal functioning of the human body. We suggest that selective allosteric modulation of IL-1 $\beta$ or IL- 6 will increase specificity while minimizing risk of unintended adverse consequences. If inflammatory amplification can be described as a series of gears together propelling one large wheel, a specific and selective inflammatory antagonist such as Rytvela could fill the role of throwing a spanner into the works, slowing the momentum of the large wheel before it reaches top speeds (Figure 2).

\section{CONCLUSION}

In this review, we present cooperativity between ligands, cells, and tissues as a hallmark of human parturition. These studies indicate, as others have proposed through the MAPS and inflammatory load hypotheses, that the accumulation of an increasing number of stimulatory interactions are involved in transitioning the state of pregnancy to the state of parturition. Mitchell and Taggart in reference to human parturition wrote, "Rather than seeking the trigger, experiments need to be designed to investigate synergistic interactions among a variety of physiological systems and tissues" (Mitchell and Taggart, 2009). Further work is required to define the specific inflammatory interactions central to term or preterm labor. For now, it is clear that inflammatory amplification due to localized paracrine interactions in the intrauterine space is an essential component of uterine transition for labor, and IL- $1 \beta$ and IL-6 act as key upstream drivers in this process. This provides a truly potent target for the development of therapies and diagnostic tests to assess when the physiology of labor is approaching term or preterm. 


\section{AUTHOR CONTRIBUTIONS}

KL prepared the manuscript with inputs from WX, MP, SC, and DO. All authors contributed to the article and approved the submitted version.

\section{FUNDING}

KL is supported by the generosity of the Stollery Children's Hospital Foundation and supporters of the Alberta Women's

\section{REFERENCES}

Adams Waldorf, K. M., Singh, N., Mohan, A. R., Young, R. C., Ngo, L., Das, A., et al. (2015). Uterine Overdistention Induces Preterm Labor Mediated by Inflammation: Observations in Pregnant Women and Nonhuman Primates. Am. J. Obstet Gynecol 213, 830.e831-830.e819. doi: 10.1016/j.ajog.2015.08.028

Akira, S., Isshiki, H., Sugita, T., Tanabe, O., Kinoshita, S., Nishio, Y., et al. (1990). A Nuclear Factor for IL-6 Expression (NF-IL6) Is a Member of a C/EBP Family. EMBO J. 9, 1897-1906. doi: 10.1002/j.1460-2075.1990.tb08316.x

Ali, M., Buhimschi, I., Chwalisz, K., and Garfield, R. E. (1997). Changes in Expression of the Nitric Oxide Synthase Isoforms in Rat Uterus and Cervix During Pregnancy and Parturition. Mol. Hum. Reprod. 3, 995-1003. doi: 10.1093/molehr/3.11.995

Al-Matubsi, H. Y., Eis, A. L., Brodt-Eppley, J., MacPhee, D. J., Lye, S., and Myatt, L. (2001). Expression and Localization of the Contractile Prostaglandin F Receptor in Pregnant Rat Myometrium in Late Gestation, Labor, and Postpartum. Biol. Reprod. 65, 1029-1037. doi: 10.1095/biolreprod65.4.1029

Amini, P., Michniuk, D., Kuo, K., Yi, L., Skomorovska-Prokvolit, Y., Peters, G. A., et al. (2016). Human Parturition Involves Phosphorylation of Progesterone Receptor-a at Serine-345 in Myometrial Cells. Endocrinology 157, 4434-4445. doi: 10.1210/en.2016-1654

Amini, P., Wilson, R., Wang, J., Tan, H., Yi, L., Koeblitz, W. K., et al. (2019). Progesterone and cAMP Synergize to Inhibit Responsiveness of Myometrial Cells to Pro-Inflammatory/Pro-Labor Stimuli. Mol. Cell Endocrinol. 479, 1-11. doi: 10.1016/j.mce.2018.08.005

Ammälä, M., Nyman, T., Salmi, A., and Rutanen, E. M. (1997). The Interleukin-1 System in Gestational Tissues at Term: Effect of Labour. Placenta 18, 717-723. doi: 10.1016/S0143-4004(97)90014-X

Arenas-Hernandez, M., Gomez-Lopez, N., Garcia-Flores, V., Rangel-Escareño, C., Alvarez-Salas, L. M., Martinez-Acuña, N., et al. (2019). Choriodecidual Leukocytes Display a Unique Gene Expression Signature in Spontaneous Labor at Term. Genes Immun. 20, 56-68. doi: 10.1038/s41435-017-0010-z

Arend, W. P. (1993). Interleukin-1 Receptor Antagonist. Adv. Immunol. 54, 167227. doi: 10.1016/S0065-2776(08)60535-0

Arthur, P., Taggart, M. J., Zielnik, B., Wong, S., and Mitchell, B. F. (2008). Relationship Between Gene Expression and Function of Uterotonic Systems in the Rat During Gestation, Uterine Activation and Both Term and Preterm Labour. J. Physiol. 586, 6063-6076. doi: 10.1113/jphysiol.2008.164004

Avrech, O. M., Golan, A., Weinraub, Z., Bukovsky, I., and Caspi, E. (1991). Mifepristone (RU486) Alone or in Combination With a Prostaglandin Analogue for Termination of Early Pregnancy: A Review. Fertil. Steril. 56, 385-393. doi: 10.1016/S0015-0282(16)54527-0

Bansal, R. K., Goldsmith, P. C., He, Y., Zaloudek, C. J., Ecker, J. L., and Riemer, R. K. (1997). A Decline in Myometrial Nitric Oxide Synthase Expression Is Associated With Labor and Delivery. J. Clin. Invest. 99, 2502-2508. doi: 10.1172/JCI119434

Bartlett, S. R., Sawdy, R., and Mann, G. E. (1999). Induction of Cyclooxygenase-2 Expression in Human Myometrial Smooth Muscle Cells by Interleukin-1beta: Involvement of p38 Mitogen-Activated Protein Kinase. J. Physiol. 520 (Pt 2), 399-406. doi: 10.1111/j.1469-7793.1999.00399.x

Behnia, F., Taylor, B. D., Woodson, M., Kacerovsky, M., Hawkins, H., Fortunato, S. J., et al. (2015). Chorioamniotic Membrane Senescence: A Signal for Parturition? Am. J. Obstet. Gynecol. 213, 359.e351-316. doi: 10.1016/j.ajog.2015.05.041

Belt, A. R., Baldassare, J. J., Molnár, M., Romero, R., and Hertelendy, F. (1999). The Nuclear Transcription Factor NF-kappaB Mediates interleukin-1beta-
Health Foundation through the Women and Children's Health Research Institute. The authors are also supported by the Canadian Institutes of Health Research \#168858.

\section{ACKNOWLEDGMENTS}

Portions of this review are included in the $\mathrm{PhD}$ thesis of $\mathrm{KL}$ which is available online (Leimert, 2018).

induced Expression of Cyclooxygenase-2 in Human Myometrial Cells. Am. J. Obstet. Gynecol. 181, 359-366. doi: 10.1016/S0002-9378(99)70562-4

Benesch, M. G., Tang, X., Dewald, J., Dong, W. F., Mackey, J. R., Hemmings, D. G., et al. (2015). Tumor-Induced Inflammation in Mammary Adipose Tissue Stimulates a Vicious Cycle of Autotaxin Expression and Breast Cancer Progression. FASEB J. 29, 3990-4000. doi: 10.1096/fj.15-274480

Bethin, K. E., Nagai, Y., Sladek, R., Asada, M., Sadovsky, Y., Hudson, T. J., et al. (2003). Microarray Analysis of Uterine Gene Expression in Mouse and Human Pregnancy. Mol. Endocrinol. 17, 1454-1469. doi: 10.1210/me.2003-0007

Beutler, B. (2009). Microbe Sensing, Positive Feedback Loops, and the Pathogenesis of Inflammatory Diseases. Immunol. Rev. 227, 248-263. doi: 10.1111/j.1600-065X.2008.00733.x

Bircher, K., Ehret, A. E., Spiess, D., Ehrbar, M., Simões-Wüst, A. P., OchsenbeinKölble, N., et al. (2019). On the Defect Tolerance of Fetal Membranes. Interface Focus 9, 20190010. doi: 10.1098/rsfs.2019.0010

Bisits, A. M., Smith, R., Mesiano, S., Yeo, G., Kwek, K., MacIntyre, D., et al. (2005). Inflammatory Aetiology of Human Myometrial Activation Tested Using Directed Graphs. PloS Comput. Biol. 1, 132-136. doi: 10.1371/journal.pcbi.0010019

Blencowe, H., Cousens, S., Oestergaard, M. Z., Chou, D., Moller, A. B., Narwal, R., et al. (2012). National, Regional, and Worldwide Estimates of Preterm Birth Rates in the Year 2010 With Time Trends Since 1990 for Selected Countries: A Systematic Analysis and Implications. Lancet 379, 2162-2172. doi: 10.1016/ S0140-6736(12)60820-4

Blesson, C. S., Roos, N., Stephansson, O., Masironi, B., Reinert, S., Stjernholm, Y. Ekman-Ordeberg, G., and Sahlin, L. (2013). Expression and Localization of Prostaglandin Receptors and Stromal Factors in Human Cervix-Variations in Pregnant and Non-Pregnant States. Open Journal of Mol Integ Physl. 3(4), 147157. doi: 10.4236/ojmip.2013.34020

Bokström, H., Brännström, M., Alexandersson, M., and Norström, A. (1997). Leukocyte Subpopulations in the Human Uterine Cervical Stroma at Early and Term Pregnancy. Hum. Reprod. 12, 586-590. doi: 10.1093/humrep/12.3.586

Bollapragada, S., Bollopragada, S., Youssef, R., Jordan, F., Greer, I., Norman, J., et al. (2009). Term Labor Is Associated With a Core Inflammatory Response in Human Fetal Membranes, Myometrium, and Cervix. Am. J. Obstet. Gynecol. 200, 104.e101-111. doi: 10.1016/j.ajog.2008.08.032

Boraschi, D., and Tagliabue, A. (2013). The Interleukin-1 Receptor Family. Semin. Immunol. 25, 394-407. doi: 10.1016/j.smim.2013.10.023

Brodt-Eppley, J., and Myatt, L. (1999). Prostaglandin Receptors in Lower Segment Myometrium During Gestation and Labor. Obstet. Gynecol. 93, 89-93. doi: 10.1016/s0029-7844(98)00378-0

Brown, N. L., Alvi, S. A., Elder, M. G., Bennett, P. R., and Sullivan, M. H. (1998). A Spontaneous Induction of Fetal Membrane Prostaglandin Production Precedes Clinical Labour. J. Endocrinol. 157, R1-R6. doi: 10.1677/joe.0.157r001

Bry, K., and Hallman, M. (1993). Transforming Growth Factor-Beta 2 Prevents Preterm Delivery Induced by Interleukin-1 Alpha and Tumor Necrosis FactorAlpha in the Rabbit. Am. J. Obstet Gynecol 168, 1318-1322. doi: 10.1016/00029378(93)90388-Y

Bulletti, C., De Ziegler, D., Albonetti, A., and Flamigni, C. (1998). Paracrine Regulation of Menstruation. J. Reprod. Immunol. 39, 89-104. doi: 10.1016/ S0165-0378(98)00015-1

Chai, M., Barker, G., Menon, R., and Lappas, M. (2012). Increased Oxidative Stress in Human Fetal Membranes Overlying the Cervix From Term Non-Labouring and Post Labour Deliveries. Placenta 33, 604-610. doi: 10.1016/ j.placenta.2012.04.014 
Chevillard, G., Derjuga, A., Devost, D., Zingg, H. H., and Blank, V. (2007). Identification of Interleukin-1beta Regulated Genes in Uterine Smooth Muscle Cells. Reproduction 134, 811-822. doi: 10.1530/REP-07-0289

Chibbar, R., Miller, F. D., and Mitchell, B. F. (1993). Synthesis of Oxytocin in Amnion, Chorion, and Decidua May Influence the Timing of Human Parturition. J. Clin. Invest. 91, 185-192. doi: 10.1172/JCI116169

Chibbar, R., Wong, S., Miller, F. D., and Mitchell, B. F. (1995). Estrogen Stimulates Oxytocin Gene Expression in Human Chorio-Decidua. J. Clin. Endocrinol. Metab. 80, 567-572. doi: 10.1210/jcem.80.2.7852522

Chin, P. Y., Dorian, C. L., Hutchinson, M. R., Olson, D. M., Rice, K. C., Moldenhauer, L. M., et al. (2016). Novel Toll-like Receptor-4 Antagonist (+)-Naloxone Protects Mice From Inflammation-Induced Preterm Birth. Sci. Rep. 6, 36112. doi: 10.1038/srep36112

Chow, L., and Lye, S. J. (1994). Expression of the Gap Junction Protein connexin-43 is Increased in the Human Myometrium Toward Term and With the Onset of Labor. Am. J. Obstet Gynecol 170, 788-795. doi: 10.1016/S0002-9378(94)70284-5

Coleman, M., Orvis, A., Wu, T. Y., Dacanay, M., Merillat, S., Ogle, J., et al. (2020). A Broad Spectrum Chemokine Inhibitor Prevents Preterm Labor But Not Microbial Invasion of the Amniotic Cavity or Neonatal Morbidity in a Non-human Primate Model. Front. Immunol. 11, 770. doi: 10.3389/fimmu.2020.00770

Committee on Understanding Premature Birth and Assuring Healthy Outcomes (2007). Preterm Birth: Causes, Consequences, and Prevention. Eds. R. E. Behrman and A. S. Butler (Washington, D.C: The National Academies Press).

Cook, J. L., Shallow, M. C., Zaragoza, D. B., Anderson, K. I., and Olson, D. M. (2003). Mouse Placental Prostaglandins Are Associated With Uterine Activation and the Timing of Birth. Biol. Reprod. 68, 579-587. doi: 10.1095/ biolreprod.102.008789

Cook, J. L., Zaragoza, D. B., Sung, D. H., and Olson, D. M. (2000). Expression of Myometrial Activation and Stimulation Genes in a Mouse Model of Preterm Labor: Myometrial Activation, Stimulation, and Preterm Labor. Endocrinology 141, 1718-1728. doi: 10.1210/endo.141.5.7474

Csapo, A. (1956). Progesterone Block. Am. J. Anat 98, 273-291. doi: 10.1002/ aja.1000980206

Dajani, N., Idriss, E., and Collins, P. L. (1994). Interleukin-6 Does Not Stimulate Rat Myometrial Contractions in an In Vitro Model. Am. J. Reprod. Immunol. 32, 248-254. doi: 10.1111/j.1600-0897.1994.tb01120.x

Di, W. L., Lachelin, G. C., McGarrigle, H. H., Thomas, N. S., and Becker, D. L. (2001). Oestriol and Oestradiol Increase Cell to Cell Communication and connexin43 Protein Expression in Human Myometrium. Mol. Hum. Reprod. 7, 671-679. doi: 10.1093/molehr/7.7.671

Döring, B., Shynlova, O., Tsui, P., Eckardt, D., Janssen-Bienhold, U., Hofmann, F., et al. (2006). Ablation of connexin43 in Uterine Smooth Muscle Cells of the Mouse Causes Delayed Parturition. J. Cell Sci. 119, 1715-1722. doi: 10.1242/jcs.02892

Dower, S. K., and Sims, J. E. (1990). Molecular Characterisation of Cytokine Receptors. Ann. Rheum. Dis. 49 (Suppl 1), 452-459.

Dudley, D. J., Branch, D. W., Edwin, S. S., and Mitchell, M. D. (1996). Induction of Preterm Birth in Mice by RU486. Biol. Reprod. 55, 992-995. doi: 10.1095/ biolreprod55.5.992

Dunlap, K. A., and Stormshak, F. (2004). Nongenomic Inhibition of Oxytocin Binding by Progesterone in the Ovine Uterus. Biol. Reprod. 70, 65-69. doi: 10.1095/biolreprod.103.020180

El-Azzamy, H., Balogh, A., Romero, R., Xu, Y., LaJeunesse, C., Plazyo, O., et al. (2017). Characteristic Changes in Decidual Gene Expression Signature in Spontaneous Term Parturition. J. Pathol. Transl. Med. 51, 264-283. doi: 10.4132/jptm.2016.12.20

Elliott, C. L., Loudon, J. A., Brown, N., Slater, D. M., Bennett, P. R., and Sullivan, M. H. (2001). Il-1beta and IL-8 in Human Fetal Membranes: Changes With Gestational Age, Labor, and Culture Conditions. Am. J. Reprod. Immunol. 46, 260-267. doi: 10.1034/j.1600-0897.2001.d01-11.x

Faggioli, L., Costanzo, C., Donadelli, M., and Palmieri, M. (2004). Activation of the Interleukin-6 Promoter by a Dominant Negative Mutant of C-Jun. Biochim. Biophys. Acta 1692, 17-24. doi: 10.1016/j.bbamcr.2004.03.001

Fang, X., Wong, S., and Mitchell, B. F. (1996). Relationships Among Sex Steroids, Oxytocin, and Their Receptors in the Rat Uterus During Late Gestation and at Parturition. Endocrinology 137, 3213-3219. doi: 10.1210/endo.137.8.8754742

Fang, X., Wong, S., and Mitchell, B. F. (1997). Effects of RU486 on Estrogen, Progesterone, Oxytocin, and Their Receptors in the Rat Uterus During Late Gestation. Endocrinology 138, 2763-2768. doi: 10.1210/endo.138.7.5247
Fang, X., Wong, S., and Mitchell, B. F. (2000). Effects of LPS and IL-6 on Oxytocin Receptor in Non-Pregnant and Pregnant Rat Uterus. Am. J. Reprod. Immunol. 44, 65-72. doi: 10.1111/j.8755-8920.2000.440201.x

Farine, T., Lye, S., and Shynlova, O. (2017). Peripheral Maternal Leukocytes are Activated in Response to Cytokines Secreted by Uterine Tissues of Pregnant Women. Cell Mol. Immunol. 14, 635-638. doi: 10.1038/cmi.2017.29

Feng, L., Antczak, B. C., Lan, L., Grotegut, C. A., Thompson, J. L., Allen, T. K., et al. (2014). Progesterone Receptor Membrane Component 1 (PGRMC1) Expression in Fetal Membranes Among Women With Preterm Premature Rupture of the Membranes (PPROM). Placenta 35, 331-333. doi: 10.1016/ j.placenta.2014.03.008

Filipovich, Y., Agrawal, V., Crawford, S. E., Fitchev, P., Qu, X., Klein, J., et al. (2015). Depletion of Polymorphonuclear Leukocytes Has No Effect on Preterm Delivery in a Mouse Model of Escherichia Coli-Induced Labor. Am. J. Obstet Gynecol 213, 697.e691-610. doi: 10.1016/j.ajog.2015.07.025

Frydman, R., Fernandez, H., Pons, J. C., and Ulmann, A. (1988). Mifepristone (RU486) and Therapeutic Late Pregnancy Termination: A Double-Blind Study of Two Different Doses. Hum. Reprod. 3, 803-806. doi: 10.1093/ oxfordjournals.humrep.a136786

Fuchs, A. R., Fuchs, F., Husslein, P., and Soloff, M. S. (1984). Oxytocin Receptors in the Human Uterus During Pregnancy and Parturition. Am. J. Obstet Gynecol 150, 734-741. doi: 10.1016/0002-9378(84)90677-X

Fuchs, A. R., Fuchs, F., Husslein, P., Soloff, M. S., and Fernström, M. J. (1982). Oxytocin Receptors and Human Parturition: A Dual Role for Oxytocin in the Initiation of Labor. Science 215, 1396-1398. doi: 10.1126/science.6278592

Garfield, R. E., Merrett, D., and Grover, A. K. (1980). Gap Junction Formation and Regulation in Myometrium. Am. J. Physiol. 239, C217-C228. doi: 10.1152/ ajpcell.1980.239.5.C217

Garfield, R. E., Sims, S., and Daniel, E. E. (1977). Gap Junctions: Their Presence and Necessity in Myometrium During Parturition. Science 198, 958-960. doi: 10.1126/science.929182

Gellersen, B., and Brosens, J. (2003). Cyclic AMP and Progesterone Receptor Cross-Talk in Human Endometrium: A Decidualizing Affair. J. Endocrinol. 178, 357-372. doi: 10.1677/joe.0.1780357

Gijsbers, K., Gouwy, M., Struyf, S., Wuyts, A., Proost, P., Opdenakker, G., et al. (2005). Gcp-2/CXCL6 Synergizes With Other Endothelial Cell-Derived Chemokines in Neutrophil Mobilization and Is Associated With Angiogenesis in Gastrointestinal Tumors. Exp. Cell Res. 303, 331-342. doi: 10.1016/j.yexcr.2004.09.027

Goepfert, A. R., Goldenberg, R. L., Andrews, W. W., Hauth, J. C., Mercer, B., Iams, J., et al. (2001). The Preterm Prediction Study: Association Between Cervical Interleukin 6 Concentration and Spontaneous Preterm Birth. National Institute of Child Health and Human Development Maternal-Fetal Medicine Units Network. Am. J. Obstet Gynecol 184, 483-488. doi: 10.1067/mob.2001.109653

Goldman, S., Weiss, A., Almalah, I., and Shalev, E. (2005). Progesterone Receptor Expression in Human Decidua and Fetal Membranes Before and After Contractions: Possible Mechanism for Functional Progesterone Withdrawal. Mol. Hum. Reprod. 11, 269-277. doi: 10.1093/molehr/gah161

Gomez-Lopez, N., Estrada-Gutierrez, G., Jimenez-Zamudio, L., Vega-Sanchez, R., and Vadillo-Ortega, F. (2009). Fetal Membranes Exhibit Selective Leukocyte Chemotaxic Activity During Human Labor. J. Reprod. Immunol. 80, 122-131. doi: 10.1016/j.jri.2009.01.002

Gomez-Lopez, N., Guilbert, L. J., and Olson, D. M. (2010). Invasion of the Leukocytes Into the Fetal-Maternal Interface During Pregnancy. J. Leukoc. Biol. 88, 625-633. doi: 10.1189/jlb.1209796

Gomez-Lopez, N., Olson, D. M., and Robertson, S. A. (2016). Interleukin-6 Controls Uterine Th9 Cells and CD8(+) T Regulatory Cells to Accelerate Parturition in Mice. Immunol. Cell Biol. 94, 79-89. doi: 10.1038/icb.2015.63

Gomez-Lopez, N., Romero, R., Xu, Y., Garcia-Flores, V., Leng, Y., Panaitescu, B., et al. (2017). Inflammasome Assembly in the Chorioamniotic Membranes During Spontaneous Labor at Term. Am. J. Reprod. Immunol. 05, 77. doi: 10.1111/aji.12648

Gomez-Lopez, N., Vadillo-Perez, L., Nessim, S., Olson, D. M., and Vadillo-Ortega, F. (2011). Choriodecidua and Amnion Exhibit Selective Leukocyte Chemotaxis During Term Human Labor. Am. J. Obstet Gynecol 204, 364.e369-316. doi: 10.1016/j.ajog.2010.11.010

Gouwy, M., Struyf, S., Catusse, J., Proost, P., and Van Damme, J. (2004). Synergy Between Proinflammatory Ligands of G Protein-Coupled Receptors in 
Neutrophil Activation and Migration. J. Leukoc. Biol. 76, 185-194. doi: 10.1189/jlb.1003479

Granström, L. M., Ekman, G. E., Malmström, A., Ulmsten, U., and Woessner, J. F. (1992). Serum Collagenase Levels in Relation to the State of the Human Cervix During Pregnancy and Labor. Am. J. Obstet. Gynecol. 167, 1284-1288. doi: 10.1016/S0002-9378(11)91701-3

Grazzini, E., Guillon, G., Mouillac, B., and Zingg, H. H. (1998). Inhibition of Oxytocin Receptor Function by Direct Binding of Progesterone. Nature 392, 509-512. doi: $10.1038 / 33176$

Gu, G., Gao, Q., Yuan, X., Huang, L., and Ge, L. (2012). Immunolocalization of Adipocytes and Prostaglandin E2 and its Four Receptor Proteins EP1, Ep2, EP3, and EP4 in the Caprine Cervix During Spontaneous Term Labor. Biol. Reprod. 86, 159, 151-110. doi: 10.1095/biolreprod.111.096040

Haddad, R., Tromp, G., Kuivaniemi, H., Chaiworapongsa, T., Kim, Y. M., Mazor, M., et al. (2006). Human Spontaneous Labor Without Histologic Chorioamnionitis Is Characterized by an Acute Inflammation Gene Expression Signature. Am. J. Obstet. Gynecol. 195, 394.e391-324. doi: 10.1016/j.ajog.2005.08.057

Hadley, E. E., Sheller-Miller, S., Saade, G., Salomon, C., Mesiano, S., Taylor, R. N., et al. (2018). Amnion Epithelial Cell-Derived Exosomes Induce Inflammatory Changes in Uterine Cells. Am. J. Obstet. Gynecol. 219, 478.e471-478.e421. doi: 10.1016/j.ajog.2018.08.021

Halgunset, J., Johnsen, H., Kjøllesdal, A. M., Qvigstad, E., Espevik, T., and Austgulen, R. (1994). Cytokine Levels in Amniotic Fluid and Inflammatory Changes in the Placenta From Normal Deliveries at Term. Eur. J. Obstet Gynecol Reprod. Biol. 56, 153-160. doi: 10.1016/0028-2243(94)90162-7

Hamilton, S., Oomomian, Y., Stephen, G., Shynlova, O., Tower, C. L., Garrod, A., et al. (2012). Macrophages Infiltrate the Human and Rat Decidua During Term and Preterm Labor: Evidence That Decidual Inflammation Precedes Labor. Biol. Reprod. 86, 39. doi: 10.1095/biolreprod.111.095505

Hamilton, S. A., Tower, C. L., and Jones, R. L. (2013). Identification of Chemokines Associated With the Recruitment of Decidual Leukocytes in Human Labour: Potential Novel Targets for Preterm Labour. PloS One 8, e56946. doi: 10.1371/journal.pone.0056946

Hanna, J., Goldman-Wohl, D., Hamani, Y., Avraham, I., Greenfield, C., NatansonYaron, S., et al. (2006). Decidual NK Cells Regulate Key Developmental Processes at the Human Fetal-Maternal Interface. Nat. Med. 12, 1065-1074. doi: $10.1038 / \mathrm{nm} 1452$

Hardy, D. B., Janowski, B. A., Corey, D. R., and Mendelson, C. R. (2006). Progesterone Receptor Plays a Major Antiinflammatory Role in Human Myometrial Cells by Antagonism of Nuclear Factor-Kappab Activation of Cyclooxygenase 2 Expression. Mol. Endocrinol. 20, 2724-2733. doi: 10.1210/ me.2006-0112

Helmig, R., Oxlund, H., Petersen, L. K., and Uldbjerg, N. (1993). Different Biomechanical Properties of Human Fetal Membranes Obtained Before and After Delivery. Eur. J. Obstet. Gynecol. Reprod. Biol. 48, 183-189. doi: 10.1016/ 0028-2243(93)90086-R

Heng, Y. J., Liong, S., Permezel, M., Rice, G. E., Di Quinzio, M. K., and Georgiou, H. M. (2014). The Interplay of the Interleukin 1 System in Pregnancy and Labor. Reprod. Sci. 21, 122-130. doi: 10.1177/1933719113492204

Hirsch, E., Filipovich, Y., and Mahendroo, M. (2006). Signaling Via the Type I IL-1 and TNF Receptors Is Necessary for Bacterially Induced Preterm Labor in a Murine Model. Am. J. Obstet. Gynecol. 194, 1334-1340. doi: 10.1016/j.ajog.2005.11.004

Hirst, J. J., Mijovic, J. E., Zakar, T., and Olson, D. M. (1998). Prostaglandin Endoperoxide H Synthase-1 and -2 mRNA Levels and Enzyme Activity in Human Decidua at Term Labor. J. Soc. Gynecol Investig. 5, 13-20. doi: 10.1177/ 107155769800500104

Hirst, J. J., Teixeira, F. J., Zakar, T., and Olson, D. M. (1995). Prostaglandin Endoperoxide-H Synthase-1 and -2 Messenger Ribonucleic Acid Levels in Human Amnion With Spontaneous Labor Onset. J. Clin. Endocrinol. Metab. 80, 517-523. doi: 10.1210/jcem.80.2.7852513

Holesh, J. E., Bass, A. N., and Lord, M. (2021). Physiology, Ovulation. In: StatPearls [Internet]. Treasure Island (FL): StatPearls Publishing. Available at: https://pubmed.ncbi.nlm.nih.gov/28723025/.

Hua, R., Pease, J. E., Sooranna, S. R., Viney, J. M., Nelson, S. M., Myatt, L., et al. (2012). Stretch and Inflammatory Cytokines Drive Myometrial Chemokine Expression Via NF-kb Activation. Endocrinology 153, 481-491. doi: 10.1210/ en.2011-1506
Ibrahim, S. A., Ackerman, W. E., Summerfield, T. L., Lockwood, C. J., Schatz, F., and Kniss, D. A. (2016). Inflammatory Gene Networks in Term Human Decidual Cells Define a Potential Signature for Cytokine-Mediated Parturition. Am. J. Obstet. Gynecol. 214, 284.e281-284.e247. doi: 10.1016/j.ajog.2015.08.075

Ishiguro, T., Takeda, J., Fang, X., Bronson, H., and Olson, D. M. (2016). Interleukin (IL)-1 in Rat Parturition: IL-1 Receptors 1 and 2 and Accessory Proteins Abundance in Pregnant Rat Uterus at Term - Regulation by Progesterone. Physiol. Rep. 4, e12866. doi: 10.14814/phy2.12866

Jacobs, S. O., Sheller-Miller, S., Richardson, L. S., Urrabaz-Garza, R., Radnaa, E., and Menon, R. (2021). Characterizing the Immune Cell Population in the Human Fetal Membrane. Am. J. Reprod. Immunol. 85, e13368. doi: 10.1111/ aji. 13368

Junqueira, L. C., Zugaib, M., Montes, G. S., Toledo, O. M., Krisztán, R. M., and Shigihara, K. M. (1980). Morphologic and Histochemical Evidence for the Occurrence of Collagenolysis and for the Role of Neutrophilic Polymorphonuclear Leukocytes During Cervical Dilation. Am. J. Obstet. Gynecol. 138, 273-281. doi: 10.1016/0002-9378(80)90248-3

Kandhaya-Pillai, R., Miro-Mur, F., Alijotas-Reig, J., Tchkonia, T., Kirkland, J. L., and Schwartz, S. (2017). Tnfo-Senescence Initiates a STAT-Dependent Positive Feedback Loop, Leading to a Sustained Interferon Signature, DNA Damage, and Cytokine Secretion. Aging (Albany NY) 9, 2411-2435. doi: 10.18632/aging.101328

Karin, M. (1995). The Regulation of AP-1 Activity by Mitogen-Activated Protein Kinases. J. Biol. Chem. 270, 16483-16486. doi: 10.1074/jbc.270.28.16483

Kastner, P., Krust, A., Turcotte, B., Stropp, U., Tora, L., Gronemeyer, H., et al. (1990). Two Distinct Estrogen-Regulated Promoters Generate Transcripts Encoding the Two Functionally Different Human Progesterone Receptor Forms A and B. EMBO J. 9, 1603-1614. doi: 10.1002/j.14602075.1990.tb08280.x

Keelan, J. A. (2018). Intrauterine Inflammatory Activation, Functional Progesterone Withdrawal, and the Timing of Term and Preterm Birth. J. Reprod. Immunol. 125, 89-99. doi: 10.1016/j.jri.2017.12.004

Keelan, J. A., Khan, S., Yosaatmadja, F., and Mitchell, M. D. (2009). Prevention of Inflammatory Activation of Human Gestational Membranes in an Ex Vivo Model Using a Pharmacological NF-kappaB Inhibitor. J. Immunol. 183, 52705278. doi: $10.4049 /$ jimmunol.0802660

Kendal-Wright, C. E. (2007). Stretching, Mechanotransduction, and Proinflammatory Cytokines in the Fetal Membranes. Reprod. Sci. 14, 35-41. doi: 10.1177/1933719107310763

Khanjani, S., Kandola, M. K., Lindstrom, T. M., Sooranna, S. R., Melchionda, M., Lee, Y. S., et al. (2011). Nf-kb Regulates a Cassette of Immune/Inflammatory Genes in Human Pregnant Myometrium at Term. J. Cell Mol. Med. 15, 809824. doi: $10.1111 / j .1582-4934.2010 .01069 . x$

Kim, S. H., MacIntyre, D. A., Firmino Da Silva, M., Blanks, A. M., Lee, Y. S., Thornton, S., et al. (2015). Oxytocin Activates NF-kb-Mediated Inflammatory Pathways in Human Gestational Tissues. Mol. Cell Endocrinol. 403, 64-77. doi: 10.1016/j.mce.2014.11.008

Kirby, M. A., Heuerman, A. C., Custer, M., Dobyns, A. E., Strilaeff, R., Stutz, K. N., et al. (2016). Progesterone Receptor-Mediated Actions Regulate Remodeling of the Cervix in Preparation for Preterm Parturition. Reprod. Sci. 23, 1473-1483. doi: $10.1177 / 1933719116650756$

Kniss, D. A., Zimmerman, P. D., Garver, C. L., and Fertel, R. H. (1997). Interleukin-1 Receptor Antagonist Blocks Interleukin-1-Induced Expression of Cyclooxygenase-2 in Endometrium. Am. J. Obstet Gynecol 177, 559-567. doi: $10.1016 /$ S0002-9378(97)70146-7

Kozuka, M., Ito, T., Hirose, S., Takahashi, K., and Hagiwara, H. (1989). Endothelin Induces Two Types of Contractions of Rat Uterus: Phasic Contractions by Way of Voltage-Dependent Calcium Channels and Developing Contractions Through a Second Type of Calcium Channels. Biochem. Biophys. Res. Commun. 159, 317-323. doi: 10.1016/0006-291X(89)92440-6

Kumar, D., Fung, W., Moore, R. M., Pandey, V., Fox, J., Stetzer, B., et al. (2006). Proinflammatory Cytokines Found in Amniotic Fluid Induce Collagen Remodeling, Apoptosis, and Biophysical Weakening of Cultured Human Fetal Membranes. Biol. Reprod. 74, 29-34. doi: 10.1095/biolreprod.105.045328

Kumar, D., Schatz, F., Moore, R. M., Mercer, B. M., Rangaswamy, N., Mansour, J. M., et al. (2011). The Effects of Thrombin and Cytokines Upon the Biomechanics and Remodeling of Isolated Amnion Membrane, In Vitro. Placenta 32, 206-213. doi: 10.1016/j.placenta.2011.01.006 
Lavery, J. P., and Miller, C. E. (1979). Deformation and Creep in the Human Chorioamniotic Sac. Am. J. Obstet. Gynecol. 134, 366-375. doi: 10.1016/S00029378(16)33077-0

Lee, Y. H., Shynlova, O., and Lye, S. J. (2015). Stretch-Induced Human Myometrial Cytokines Enhance Immune Cell Recruitment Via Endothelial Activation. Cell Mol. Immunol. 12, 231-242. doi: 10.1038/cmi.2014.39

Lee, H., Yin, N., Liu, Z., Wang, L., Ran, Y., Chen, J., et al. (2020). Characteristics of Enhanced Leukocyte Chemotaxis at Term \& Preterm Labour. Society for Reproductive Investigation- 67th Annual Scientific Meeting. SRI 2020: Scientific Abstracts. Reprod. Sci. 27, 1-444. doi: 10.1007/s43032-020-00176-9

Lefebvre, D. L., Piersanti, M., Bai, X. H., Chen, Z. Q., and Lye, S. J. (1995). Myometrial Transcriptional Regulation of the Gap Junction Gene, Connexin43. Reprod. Fertil. Dev. 7, 603-611. doi: 10.1071/RD9950603

Leimert, K. B. (2018). Intrauterine Cooperativity: Amplification Between Ligands, Cells, and Tissues to Transition the Uterus for Parturition University of Alberta. doi: 10.7939/R3P26QK3S

Leimert, K. B., Messer, A., Gray, T., Fang, X., Chemtob, S., and Olson, D. M. (2019). Maternal and Fetal Intrauterine Tissue Crosstalk Promotes ProInflammatory Amplification and Uterine Transition. Biol. Reprod. 100, 783797. doi: 10.1093/biolre/ioy232

Leimert, K. B., Verstraeten, B. S. E., Messer, A., Nemati, R., Blackadar, K., Fang, X., et al. (2019). Cooperative Effects of Sequential PGF2 $\alpha$ and IL-1 $\beta$ on IL-6 and COX-2 Expression in Human Myometrial Cells $\dagger$. Biol. Reprod. 100, 13701385. doi: 10.1093/biolre/ioz029

Leonhardt, S. A., Boonyaratanakornkit, V., and Edwards, D. P. (2003). Progesterone Receptor Transcription and Non-Transcription Signaling Mechanisms. Steroids 68, 761-770. doi: 10.1016/S0039-128X(03)00129-6

Liggins, G. (1981). "Cervical Ripening as an Inflammatory Reaction” In: D. A. Ellwood and A. B. M. Anderson, editors. The Cervix in Pregnancy and Labour, Clinical and Biochemical Investigation. Churchill Livingston 1-9.

Lim, S., MacIntyre, D. A., Lee, Y. S., Khanjani, S., Terzidou, V., Teoh, T. G., et al. (2012). Nuclear Factor Kappa B Activation Occurs in the Amnion Prior to Labour Onset and Modulates the Expression of Numerous Labour Associated Genes. PloS One 7, e34707. doi: 10.1371/journal.pone.0034707

Loudon, J. A., Elliott, C. L., Hills, F., and Bennett, P. R. (2003). Progesterone Represses Interleukin-8 and Cyclo-Oxygenase-2 in Human Lower Segment Fibroblast Cells and Amnion Epithelial Cells. Biol. Reprod. 69, 331-337. doi: 10.1095/biolreprod.102.013698

Loudon, J. A., Sooranna, S. R., Bennett, P. R., and Johnson, M. R. (2004). Mechanical Stretch of Human Uterine Smooth Muscle Cells Increases IL-8 mRNA Expression and Peptide Synthesis. Mol. Hum. Reprod. 10, 895-899. doi: 10.1093/molehr/gah112

Lozovyy, V., Richardson, L., Saade, G., and Menon, R. (2021). Progesterone Receptor Membrane Components: Key Regulators of Fetal Membrane Integrity. Biol. Reprod. 02, 104:445-456. doi: 10.1093/biolre/ioaa192

Lui, S., Duval, C., Farrokhnia, F., Girard, S., Harris, L. K., Tower, C. L., et al. (2018). Delineating Differential Regulatory Signatures of the Human Transcriptome in the Choriodecidua and Myometrium at Term Labor. Biol. Reprod. 98, 422-436. doi: 10.1093/biolre/iox186

Lye, S. J., Nicholson, B. J., Mascarenhas, M., MacKenzie, L., and Petrocelli, T. (1993). Increased Expression of connexin-43 in the Rat Myometrium During Labor Is Associated With an Increase in the Plasma Estrogen:Progesterone Ratio. Endocrinology 132, 2380-2386. doi: 10.1210/endo.132.6.8389279

Madsen, G., Zakar, T., Ku, C. Y., Sanborn, B. M., Smith, R., and Mesiano, S. (2004). Prostaglandins Differentially Modulate Progesterone Receptor-a and -B Expression in Human Myometrial Cells: Evidence for Prostaglandin-Induced Functional Progesterone Withdrawal. J. Clin. Endocrinol. Metab. 89, 10101013. doi: 10.1210/jc.2003-031037

Maehara, K., Kanayama, N., Maradny, E. E., Uezato, T., Fujita, M., and Terao, T. (1996). Mechanical Stretching Induces Interleukin-8 Gene Expression in Fetal Membranes: A Possible Role for the Initiation of Human Parturition. Eur. J. Obstet Gynecol Reprod. Biol. 70, 191-196. doi: 10.1016/S0301-2115(95)02602-9

Maiti, K., Paul, J. W., Read, M., Chan, E. C., Riley, S. C., Nahar, P., et al. (2011). G-1activated Membrane Estrogen Receptors Mediate Increased Contractility of the Human Myometrium. Endocrinology 152, 2448-2455. doi: 10.1210/en.2010-0979

Makino, S., Zaragoza, D. B., Mitchell, B. F., Yonemoto, H., and Olson, D. M. (2007). Decidual Activation: Abundance and Localization of Prostaglandin F2alpha Receptor (FP) mRNA and Protein and Uterine Activation Proteins in
Human Decidua at Preterm Birth and Term Birth. Placenta 28, 557-565. doi: 10.1016/j.placenta.2006.06.010

Malak, T. M., Ockleford, C. D., Bell, S. C., Dalgleish, R., Bright, N., and Macvicar, J. (1993). Confocal Immunofluorescence Localization of Collagen Types I, III, IV, V and VI and Their Ultrastructural Organization in Term Human Fetal Membranes. Placenta 14, 385-406. doi: 10.1016/S0143-4004(05)80460-6

Manabe, Y., Manabe, A., and Takahashi, A. (1982). F Prostaglandin Levels in Amniotic Fluid During Balloon-Induced Cervical Softening and Labor at Term. Prostaglandins 23, 247-256. doi: 10.1016/0090-6980(82)90052-1

March of Dimes, The Partnership for Maternal Newborn \& Child Health, Save the Children and World Health Organization (2012). March of Dimes, PMNCH, Save the Children, WHO. Born Too Soon: The Global Action Report on Preterm Birth. Eds C. P. Howson, M. V. Kinney and J. E. Lawn (Geneva: World Health Organization).

Marczin, N., Papapetropoulos, A., and Catravas, J. D. (1993). Tyrosine Kinase Inhibitors Suppress Endotoxin- and IL-1 Beta-Induced NO Synthesis in Aortic Smooth Muscle Cells. Am. J. Physiol. 265, H1014-H1018. doi: 10.1152/ ajpheart.1993.265.3.H1014

Matsusaka, T., Fujikawa, K., Nishio, Y., Mukaida, N., Matsushima, K., Kishimoto, T., et al. (1993). Transcription Factors NF-IL6 and NF-Kappa B Synergistically Activate Transcription of the Inflammatory Cytokines, Interleukin 6 and Interleukin 8. Proc. Natl. Acad. Sci. U.S.A. 90, 10193-10197. doi: 10.1073/pnas.90.21.10193

McLaren, J., Taylor, D. J., and Bell, S. C. (2000). Increased Concentration of ProMatrix Metalloproteinase 9 in Term Fetal Membranes Overlying the Cervix Before Labor: Implications for Membrane Remodeling and Rupture. Am. J. Obstet Gynecol 182, 409-416. doi: 10.1016/S0002-9378(00)70232-8

Menon, R., Bonney, E. A., Condon, J., Mesiano, S., and Taylor, R. N. (2016). Novel Concepts on Pregnancy Clocks and Alarms: Redundancy and Synergy in Human Parturition. Hum. Reprod. 22, 535-60. doi: 10.1093/humupd/dmw022

Menon, R., Mesiano, S., and Taylor, R. N. (2017). Programmed Fetal Membrane Senescence and Exosome-Mediated Signaling: A Mechanism Associated With Timing of Human Parturition. Front. Endocrinol. (Lausanne) 8, 196. doi: 10.3389/fendo.2017.00196

Menssen, A., Hydbring, P., Kapelle, K., Vervoorts, J., Diebold, J., Lüscher, B., et al. (2012). The c-MYC Oncoprotein, the NAMPT Enzyme, the SIRT1-inhibitor DBC1, and the SIRT1 Deacetylase Form a Positive Feedback Loop. Proc. Natl. Acad. Sci. U.S.A. 109, E187-E196. doi: 10.1073/pnas.1105304109

Menzies, F. M., Higgins, C. A., Shepherd, M. C., Nibbs, R. J., and Nelson, S. M. (2012). Mast Cells Reside in Myometrium and Cervix, But Are Dispensable in Mice for Successful Pregnancy and Labor. Immunol. Cell Biol. 90, 321-329. doi: 10.1038/icb.2011.40

Merlino, A., Welsh, T., Erdonmez, T., Madsen, G., Zakar, T., Smith, R., et al. (2009). Nuclear Progesterone Receptor Expression in the Human Fetal Membranes and Decidua at Term Before and After Labor. Reprod. Sci. 16, 357-363. doi: 10.1177/1933719108328616

Merlino, A. A., Welsh, T. N., Tan, H., Yi, L. J., Cannon, V., Mercer, B. M., et al. (2007). Nuclear Progesterone Receptors in the Human Pregnancy Myometrium: Evidence That Parturition Involves Functional Progesterone Withdrawal Mediated by Increased Expression of Progesterone Receptor-a. J. Clin. Endocrinol. Metab. 92, 1927-1933. doi: 10.1210/jc.2007-0077

Mesiano, S., Chan, E. C., Fitter, J. T., Kwek, K., Yeo, G., and Smith, R. (2002). Progesterone Withdrawal and Estrogen Activation in Human Parturition Are Coordinated by Progesterone Receptor A Expression in the Myometrium. J. Clin. Endocrinol. Metab. 87, 2924-2930. doi: 10.1210/jcem.87.6.8609

Migale, R., MacIntyre, D. A., Cacciatore, S., Lee, Y. S., Hagberg, H., Herbert, B. R., et al. (2016). Modeling Hormonal and Inflammatory Contributions to Preterm and Term Labor Using Uterine Temporal Transcriptomics. BMC Med. 14, 86. doi: 10.1186/s12916-016-0632-4

Mijovic, J. E., Zakar, T., Nairn, T. K., and Olson, D. M. (1997). ProstaglandinEndoperoxide $\mathrm{H}$ Synthase-2 Expression and Activity Increases With Term Labor in Human Chorion. Am. J. Physiol. 272, E832-E840. doi: 10.1152/ ajpendo.1997.272.5.E832

Mitchell, M. D., Dudley, D. J., Edwin, S. S., and Schiller, S. L. (1991). Interleukin-6 Stimulates Prostaglandin Production by Human Amnion and Decidual Cells. Eur. J. Pharmacol. 192, 189-191. doi: 10.1016/0014-2999(91)90090-D

Mitchell, M. D., Edwin, S., and Romero, R. J. (1990). Prostaglandin Biosynthesis by Human Decidual Cells: Effects of Inflammatory Mediators. Prostaglandins Leukot. Essent. Fatty Acids 41, 35-38. doi: 10.1016/0952-3278(90)90128-8 
Mitchell, B. F., and Powell, W. A. (1984). Progesterone Production by Human Fetal Membranes: An In Vitro Incubation System for Studying Hormone Production and Metabolism. Am. J. Obstet. Gynecol. 148, 303-309. doi: 10.1016/S0002-9378(84)80073-3

Mitchell, B. F., and Taggart, M. J. (2009). Are Animal Models Relevant to Key Aspects of Human Parturition? Am. J. Physiol. Regul. Integr. Comp. Physiol. 297, R525-R545. doi: 10.1152/ajpregu.00153.2009

Mittal, P., Romero, R., Tarca, A. L., Gonzalez, J., Draghici, S., Xu, Y., et al. (2010). Characterization of the Myometrial Transcriptome and Biological Pathways of Spontaneous Human Labor at Term. J. Perinat. Med. 38, 617-643. doi: 10.1515/jpm.2010.097

Molet, S., Furukawa, K., Maghazechi, A., Hamid, Q., and Giaid, A. (2000). Chemokine- and Cytokine-Induced Expression of Endothelin 1 and Endothelin-Converting Enzyme 1 in Endothelial Cells. J. Allergy Clin. Immunol. 105, 333-338. doi: 10.1016/S0091-6749(00)90084-8

Molnár, M., Romero, R., and Hertelendy, F. (1993). Interleukin-1 and Tumor Necrosis Factor Stimulate Arachidonic Acid Release and Phospholipid Metabolism in Human Myometrial Cells. Am. J. Obstet Gynecol 169, 825829. doi: 10.1016/0002-9378(93)90011-7

Mori, M., Bogdan, A., Balassa, T., Csabai, T., and Szekeres-Bartho, J. (2016). The Decidua-the Maternal Bed Embracing the Embryo-Maintains the Pregnancy. Semin. Immunopathol. 38, 635-649. doi: 10.1007/s00281-016-0574-0

Murr, S. M., Stabenfeldt, G. H., Bradford, G. E., and Geschwind, I. I. (1974). Plasma Progesterone During Pregnancy in the Mouse. Endocrinology 94, 12091211. doi: 10.1210/endo-94-4-1209

Nadeau-Vallée, M., Boudreault, A., Leimert, K., Hou, X., Obari, D., Madaan, A., et al. (2016). Uterotonic Neuromedin U Receptor 2 and Its Ligands Are Upregulated by Inflammation in Mice and Humans, and Elicit Preterm Birth. Biol. Reprod. 95, 72. doi: 10.1095/biolreprod.116.140905

Nadeau-Vallée, M., Chin, P. Y., Belarbi, L., Brien, M., Pundir, S., Berryer, M. H., et al. (2017). Antenatal Suppression of IL-1 Protects Against InflammationInduced Fetal Injury and Improves Neonatal and Developmental Outcomes in Mice. J. Immunol. 198, 2047-2062. doi: 10.4049/jimmunol.1601600

Nadeau-Vallée, M., Obari, D., Palacios, J., Brien, M., Duval, C., Chemtob, S., et al. (2016). Sterile Inflammation and Pregnancy Complications: A Review. Reproduction 152, R277-R292. doi: 10.1530/REP-16-0453

Nadeau-Vallée, M., Quiniou, C., Palacios, J., Hou, X., Erfani, A., Madaan, A., et al. (2015). Novel Noncompetitive Il-1 Receptor-Biased Ligand Prevents Infectionand Inflammation-Induced Preterm Birth. J. Immunol. 195, 3402-3415. doi: 10.4049/jimmunol.1500758

Nadeem, L., Shynlova, O., Mesiano, S., and Lye, S. (2017). Progesterone Via Its Type-A Receptor Promotes Myometrial Gap Junction Coupling. Sci. Rep. 7, 13357. doi: 10.1038/s41598-017-13488-9

Okazaki, T., Casey, M. L., Okita, J. R., MacDonald, P. C., and Johnston, J. M. (1981). Initiation of Human Parturition. XII. Biosynthesis and Metabolism of Prostaglandins in Human Fetal Membranes and Uterine Decidua. Am. J. Obstet Gynecol 139, 373-381. doi: 10.1016/0002-9378(81)90312-4

Olson, D. M., Christiaens, I., Gracie, S., Yamamoto, Y., and Mitchell, B. F. (2008). Emerging Tocolytics: Challenges in Designing and Testing Drugs to Delay Preterm Delivery and Prolong Pregnancy. Expert Opin. Emerg. Drugs 13, 695707. doi: 10.1517/14728210802568764

Olson, D. M., Mijovic, J. E., and Sadowsky, D. W. (1995). Control of Human Parturition. Semin. Perinatol 19, 52-63. doi: 10.1016/S0146-0005(95)80047-6

Opsjłn, S. L., Wathen, N. C., Tingulstad, S., Wiedswang, G., Sundan, A., Waage, A., et al. (1993). Tumor Necrosis Factor, Interleukin-1, and Interleukin-6 in Normal Human Pregnancy. Am. J. Obstet Gynecol 169, 397-404. doi: 10.1016/0002-9378(93)90096-2

Osman, I., Young, A., Ledingham, M. A., Thomson, A. J., Jordan, F., Greer, I. A., et al. (2003). Leukocyte Density and Pro-Inflammatory Cytokine Expression in Human Fetal Membranes, Decidua, Cervix and Myometrium Before and During Labour at Term. Mol. Hum. Reprod. 9, 41-45. doi: 10.1093/molehr/gag001

Osmers, R., Rath, W., Adelmann-Grill, B. C., Fittkow, C., Kuloczik, M., Szeverényi, M., et al. (1992). Origin of Cervical Collagenase During Parturition. Am. J. Obstet Gynecol 166, 1455-1460. doi: 10.1016/0002-9378(92)91619-L

Osmers, R., Rath, W., Pflanz, M. A., Kuhn, W., Stuhlsatz, H. W., and Szeverényi, M. (1993). Glycosaminoglycans in Cervical Connective Tissue During Pregnancy and Parturition. Obstet. Gynecol. 81, 88-92.

Ou, C. W., Chen, Z. Q., Qi, S., and Lye, S. J. (1998). Increased Expression of the Rat Myometrial Oxytocin Receptor Messenger Ribonucleic Acid During Labor
Requires Both Mechanical and Hormonal Signals. Biol. Reprod. 59, 1055-1061. doi: 10.1095/biolreprod59.5.1055

Ou, C. W., Orsino, A., and Lye, S. J. (1997). Expression of connexin-43 and connexin-26 in the Rat Myometrium During Pregnancy and Labor Is Differentially Regulated by Mechanical and Hormonal Signals. Endocrinology 138, 5398-5407. doi: 10.1210/endo.138.12.5624

Parry-Jones, E., and Priya, S. (1976). A Study of the Elasticity and Tension of Fetal Membranes and of the Relation of the Area of the Gestational Sac to the Area of the Uterine Cavity. Br. J. Obstet. Gynaecol. 83, 205-212. doi: 10.1111/j.14710528.1976.tb00810.x

Patrick, J., Campbell, K., Carmichael, L., Natale, R., and Richardson, B. (1982). Patterns of Gross Fetal Body Movements Over 24-Hour Observation Intervals During the Last 10 Weeks of Pregnancy. Am. J. Obstet. Gynecol. 142, 363-371. doi: 10.1016/S0002-9378(16)32375-4

Payne, K. J., Clyde, L. A., Weldon, A. J., Milford, T. A., and Yellon, S. M. (2012). Residency and Activation of Myeloid Cells During Remodeling of the Prepartum Murine Cervix. Biol. Reprod. 87, 106. doi: 10.1095/biolreprod.112.101840

Peters, G. A., Yi, L., Skomorovska-Prokvolit, Y., Patel, B., Amini, P., Tan, H., et al. (2017). Inflammatory Stimuli Increase Progesterone Receptor-a Stability and Transrepressive Activity in Myometrial Cells. Endocrinology 158, 158-169. doi: 10.1210/en.2016-1537

Pollard, J. K., Thai, D., and Mitchell, M. D. (1993). Evidence for a Common Mechanism of Action of Interleukin-1 Beta, Tumor Necrosis Factor-Alpha, and Epidermal Growth Factor on Prostaglandin Production in Human Chorion Cells. Am. J. Reprod. Immunol. 30, 146-153. doi: 10.1111/j.1600-0897.1993.tb00615.x

Prins, J. R., Gomez-Lopez, N., and Robertson, S. A. (2012). Interleukin-6 in Pregnancy and Gestational Disorders. J. Reprod. Immunol. 95, 1-14. doi: 10.1016/j.jri.2012.05.004

Puthiyachirakkal, M., Lemerand, K., Kumar, D., Moore, R., Philipson, E., Mercer, B. M., et al. (2013). Thrombin Weakens the Amnion Extracellular Matrix (ECM) Directly Rather Than Through Protease Activated Receptors. Placenta 34, 924-931. doi: 10.1016/j.placenta.2013.07.064

Rajagopal, S. P., Hutchinson, J. L., Dorward, D. A., Rossi, A. G., and Norman, J. E. (2015). Crosstalk Between Monocytes and Myometrial Smooth Muscle in Culture Generates Synergistic Pro-Inflammatory Cytokine Production and Enhances Myocyte Contraction, With Effects Opposed by Progesterone. Mol. Hum. Reprod. 21, 672-686. doi: 10.1093/molehr/gav027

Rauk, P. N., and Chiao, J. P. (2000). Interleukin-1 Stimulates Human Uterine Prostaglandin Production Through Induction of Cyclooxygenase-2 Expression. Am. J. Reprod. Immunol. 43, 152-159. doi: 10.1111/j.8755-8920.2000.430304.x

Rauk, P. N., and Friebe-Hoffmann, U. (2000). Interleukin-1 Beta Down-Regulates the Oxytocin Receptor in Cultured Uterine Smooth Muscle Cells. Am. J. Reprod. Immunol. 43, 85-91. doi: 10.1111/j.8755-8920.2000.430204.X

Richardson, L., Gnecco, J., Ding, T., Osteen, K., Rogers, L. M., Aronoff, D. M., et al. (2019). Fetal Membrane Organ-on-Chip: An Innovative Approach to Study Cellular Interactions. Reprod. Sci., 1933719119828084. doi: 10.1177/1933719119828084

Richardson, L. S., Kim, S., Han, A., and Menon, R. (2020). Modeling Ascending Infection With a Feto-Maternal Interface Organ-on-Chip. Lab. Chip 20, 44864501. doi: 10.1039/D0LC00875C

Rinaldi, S. F., Catalano, R. D., Wade, J., Rossi, A. G., and Norman, J. E. (2014). Decidual Neutrophil Infiltration is Not Required for Preterm Birth in a Mouse Model of Infection-Induced Preterm Labor. J. Immunol. 192, 2315-2325. doi: 10.4049/jimmunol.1302891

Robertson, S. A., Christiaens, I., Dorian, C. L., Zaragoza, D. B., Care, A.S., Banks, A. M., et al. (2010). Interleukin-6 Is an Essential Determinant of On-Time Parturition in the Mouse. Endocrinology 151, 3996-4006. doi: 10.1210/en.2010-0063

Romero, R., Durum, S., Dinarello, C. A., Oyarzun, E., Hobbins, J. C., and Mitchell, M. D. (1989). Interleukin-1 Stimulates Prostaglandin Biosynthesis by Human Amnion. Prostaglandins 37, 13-22. doi: 10.1016/0090-6980(89)90028-2

Romero, R., Mazor, M., Brandt, F., Sepulveda, W., Avila, C., Cotton, D. B., et al. (1992). Interleukin-1 Alpha and Interleukin-1 Beta in Preterm and Term Human Parturition. Am. J. Reprod. Immunol. 27, 117-123. doi: 10.1111/j.16000897.1992.tb00737.x

Romero, R., Mazor, M., and Tartakovsky, B. (1991). Systemic Administration of Interleukin-1 Induces Preterm Parturition in Mice. Am. J. Obstet Gynecol 165, 969-971. doi: 10.1016/0002-9378(91)90450-6

Romero, R., Miranda, J., Chaiworapongsa, T., Korzeniewski, S. J., Chaemsaithong, P., Gotsch, F., et al. (2014). Prevalence and Clinical Significance of Sterile Intra- 
Amniotic Inflammation in Patients With Preterm Labor and Intact Membranes. Am. J. Reprod. Immunol. 72, 458-474. doi: 10.1111/aji.12296

Romero, R., Munoz, H., Gomez, R., Parra, M., Polanco, M., Valverde, V., et al. (1996). Increase in Prostaglandin Bioavailability Precedes the Onset of Human Parturition. Prostaglandins Leukot. Essent. Fatty Acids 54, 187-191. doi: 10.1016/S0952-3278(96)90015-0

Romero, R., Parvizi, S. T., Oyarzun, E., Mazor, M., Wu, Y. K., Avila, C., et al. (1990). Amniotic Fluid Interleukin-1 in Spontaneous Labor at Term. J. Reprod. Med. 35, 235-238.

Romero, R., Xu, Y., Plazyo, O., Chaemsaithong, P., Chaiworapongsa, T., Unkel, R., et al. (2018). A Role for the Inflammasome in Spontaneous Labor at Term. Am. J. Reprod. Immunol. 79, e12440. doi: 10.1111/aji.12440

Sadowsky, D. W., Adams, K. M., Gravett, M. G., Witkin, S. S., and Novy, M. J. (2006). Preterm Labor is Induced by Intraamniotic Infusions of interleukinlbeta and Tumor Necrosis Factor-Alpha But Not by Interleukin-6 or Interleukin-8 in a Nonhuman Primate Model. Am. J. Obstet Gynecol 195, 1578-1589. doi: 10.1016/j.ajog.2006.06.072

Sanyal, M. K. (1978). Secretion of Progesterone During Gestation in the Rat. J. Endocrinol. 79, 179-190. doi: 10.1677/joe.0.0790179

Sartorius, C. A., Melville, M. Y., Hovland, A. R., Tung, L., Takimoto, G. S., and Horwitz, K. B. (1994). A Third Transactivation Function (AF3) of Human Progesterone Receptors Located in the Unique N-terminal Segment of the B-Isoform. Mol. Endocrinol. 8, 1347-1360. doi: 10.1210/mend.8.10.7854352

Schmid, B., Wong, S., and Mitchell, B. F. (2001). Transcriptional Regulation of Oxytocin Receptor by interleukin-1beta and Interleukin-6. Endocrinology 142, 1380-1385. doi: 10.1210/endo.142.4.8107

Seavey, M. M., and Mosmann, T. R. (2008). Immunoregulation of Fetal and AntiPaternal Immune Responses. Immunol. Res. 40, 97-113. doi: 10.1007/s12026007-8005-x

Seckinger, P., Lowenthal, J. W., Williamson, K., Dayer, J. M., and MacDonald, H. R. (1987). A Urine Inhibitor of Interleukin 1 Activity That Blocks Ligand Binding. J. Immunol. 139, 1546-1549.

Sennström, M. B., Ekman, G., Westergren-Thorsson, G., Malmström, A., Byström, B., Endrésen, U., et al. (2000). Human Cervical Ripening, an Inflammatory Process Mediated by Cytokines. Mol. Hum. Reprod. 6, 375-381. doi: 10.1093/molehr/6.4.375

Shankar, R., Johnson, M. P., Williamson, N. A., Cullinane, F., Purcell, A. W., Moses, E. K., et al. (2010). Molecular Markers of Preterm Labor in the Choriodecidua. Reprod. Sci. 17, 297-310. doi: 10.1177/1933719109353454

Sharp, G. C., Hutchinson, J. L., Hibbert, N., Freeman, T. C., Saunders, P. T., and Norman, J. E. (2016). Transcription Analysis of the Myometrium of Labouring and NonLabouring Women. PloS One 11, e0155413. doi: 10.1371/journal.pone.0155413

Sheller-Miller, S., Trivedi, J., Yellon, S. M., and Menon, R. (2019). Exosomes Cause Preterm Birth in Mice: Evidence for Paracrine Signaling in Pregnancy. Sci. Rep. 9, 608. doi: $10.1038 / \mathrm{s} 41598-018-37002-x$

Shi, L., Shi, S. Q., Saade, G. R., Chwalisz, K., and Garfield, R. E. (1999). Changes in Cervical Resistance and Collagen Fluorescence During Gestation in Rats. J. Perinat Med. 27, 188-194. doi: 10.1515/JPM.1999.026

Shynlova, O., Dorogin, A., Li, Y., and Lye, S. (2014). Inhibition of InfectionMediated Preterm Birth by Administration of Broad Spectrum Chemokine Inhibitor in Mice. J. Cell Mol. Med. 18, 1816-1829. doi: 10.1111/jcmm.12307

Shynlova, O., Nedd-Roderique, T., Li, Y., Dorogin, A., and Lye, S. J. (2013). Myometrial Immune Cells Contribute to Term Parturition, Preterm Labour and Post-Partum Involution in Mice. J. Cell Mol. Med. 17, 90-102. doi: 10.1111/j.1582-4934.2012.01650.x

Sims, S. M., Daniel, E. E., and Garfield, R. E. (1982). Improved Electrical Coupling in Uterine Smooth Muscle is Associated With Increased Numbers of Gap Junctions at Parturition. J. Gen. Physiol. 80, 353-375. doi: 10.1085/jgp.80.3.353

Singer, C. F., Kubista, E., Garmroudi, F., and Cullen, K. J. (2000). Local Feedback Mechanisms in Human Breast Cancer. Breast Cancer Res. Treat 63, 95-104. doi: 10.1023/A:1006430202101

Skinner, K. A., and Challis, J. R. (1985). Changes in the Synthesis and Metabolism of Prostaglandins by Human Fetal Membranes and Decidua at Labor. Am. J. Obstet. Gynecol. 151, 519-523. doi: 10.1016/0002-9378(85)90281-9

Slater, D. M., Berger, L. C., Newton, R., Moore, G. E., and Bennett, P. R. (1995). Expression of Cyclooxygenase Types 1 and 2 in Human Fetal Membranes at Term. Am. J. Obstet. Gynecol. 172, 77-82. doi: 10.1016/0002-9378(95)90087-X

Soloff, M. S., Fernstrom, M. A., Periyasamy, S., Soloff, S., Baldwin, S., and Wieder, M. (1983). Regulation of Oxytocin Receptor Concentration in Rat Uterine
Explants by Estrogen and Progesterone. Can. J. Biochem. Cell Biol. 61, 625-630. doi: 10.1139/o83-078

Sooranna, S. R., Lee, Y., Kim, L. U., Mohan, A. R., Bennett, P. R., and Johnson, M. R. (2004). Mechanical Stretch Activates Type 2 Cyclooxygenase Via Activator Protein-1 Transcription Factor in Human Myometrial Cells. Mol. Hum. Reprod. 10, 109-113. doi: 10.1093/molehr/gah021

Spooren, A., Kooijman, R., Lintermans, B., Van Craenenbroeck, K., Vermeulen, L., Haegeman, G., et al. (2010). Cooperation of NFkappaB and CREB to Induce Synergistic IL-6 Expression in Astrocytes. Cell Signal 22, 871-881. doi: 10.1016/j.cellsig.2010.01.018

Stelzer, I. A., Ghaemi, M. S., Han, X., Ando, K., Hédou, J. J., Feyaerts, D., et al. (2021). Integrated Trajectories of the Maternal Metabolome, Proteome, and Immunome Predict Labor Onset. Sci. Transl. Med. 13, eabd9898. doi: 10.1126/ scitranslmed.abd 9898

Stephen, G. L., Lui, S., Hamilton, S. A., Tower, C. L., Harris, L. K., Stevens, A., et al. (2015). Transcriptomic Profiling of Human Choriodecidua During Term Labor: Inflammation as a Key Driver of Labor. Am. J. Reprod. Immunol. 73, 36-55. doi: 10.1111/aji.12328

Stjernholm, Y., Sahlin, L., Akerberg, S., Elinder, A., Eriksson, H. A., Malmström, A., et al. (1996). Cervical Ripening in Humans: Potential Roles of Estrogen, Progesterone, and Insulin-Like Growth Factor-I. Am. J. Obstet Gynecol 174, 1065-1071. doi: 10.1016/S0002-9378(96)70352-6

Takeda, J., Fang, X., and Olson, D. M. (2017). Pregnant Human Peripheral Leukocyte Migration During Several Late Pregnancy Clinical Conditions: A Cross-Sectional Observational Study. BMC Pregnancy Childbirth 17, 16. doi: 10.1186/s12884-016-1204-5

Talati, A. N., Hackney, D. N., and Mesiano, S. (2017). Pathophysiology of Preterm Labor With Intact Membranes. Semin. Perinatol. 41, 420-426. doi: 10.1053/ j.semperi.2017.07.013

Tantengco, O. A. G., Richardson, L. S., Medina, P. M. B., Han, A., and Menon, R. (2021). Organ-on-chip of the Cervical Epithelial Layer: A Platform to Study Normal and Pathological Cellular Remodeling of the Cervix. FASEB J. 35, e21463. doi: 10.1096/fj.202002590RRR

Tan, H., Yi, L., Rote, N. S., Hurd, W. W., and Mesiano, S. (2012). Progesterone Receptor-a and -B Have Opposite Effects on Proinflammatory Gene Expression in Human Myometrial Cells: Implications for Progesterone Actions in Human Pregnancy and Parturition. J. Clin. Endocrinol. Metab. 97, E719-E730. doi: 10.1210/jc.2011-3251

Terzidou, V., Sooranna, S. R., Kim, L. U., Thornton, S., Bennett, P. R., and Johnson, M. R. (2005). Mechanical Stretch Up-Regulates the Human Oxytocin Receptor in Primary Human Uterine Myocytes. J. Clin. Endocrinol. Metab. 90, 237-246. doi: 10.1210/jc.2004-0277

Thomson, A. J., Telfer, J. F., Young, A., Campbell, S., Stewart, C. J., Cameron, I. T., et al. (1999). Leukocytes Infiltrate the Myometrium During Human Parturition: Further Evidence That Labour is an Inflammatory Process. Hum. Reprod. 14, 229-236. doi: 10.1093/humrep/14.1.229

Timmons, B., Akins, M., and Mahendroo, M. (2010). Cervical Remodeling During Pregnancy and Parturition. Trends Endocrinol. Metab. 21, 353-361. doi: 10.1016/j.tem.2010.01.011

Timmons, B. C., and Mahendroo, M. S. (2006). Timing of Neutrophil Activation and Expression of Proinflammatory Markers do Not Support a Role for Neutrophils in Cervical Ripening in the Mouse. Biol. Reprod. 74, 236-245. doi: 10.1095/biolreprod.105.044891

Tonon, R., and D'Andrea, P. (2000). Interleukin-1beta Increases the Functional Expression of Connexin 43 in Articular Chondrocytes: Evidence for a Ca2+dependent Mechanism. J. Bone Miner Res. 15, 1669-1677. doi: 10.1359/ jbmr.2000.15.9.1669

Tribe, R. M., Moriarty, P., Dalrymple, A., Hassoni, A. A., and Poston, L. (2003). Interleukin-1beta Induces Calcium Transients and Enhances Basal and Store Operated Calcium Entry in Human Myometrial Smooth Muscle. Biol. Reprod. 68, 1842-1849. doi: 10.1095/biolreprod.102.011403

Uldbjerg, N., Ekman, G., Malmström, A., Olsson, K., and Ulmsten, U. (1983). Ripening of the Human Uterine Cervix Related to Changes in Collagen, Glycosaminoglycans, and Collagenolytic Activity. Am. J. Obstet Gynecol 147, 662-666. doi: 10.1016/0002-9378(83)90446-5

Ulug, U., Goldman, S., Ben-Shlomo, I., and Shalev, E. (2001). Matrix Metalloproteinase (MMP)-2 and MMP-9 and Their Inhibitor, TIMP-1, in Human Term Decidua and Fetal Membranes: The Effect of Prostaglandin F 
(2alpha) and Indomethacin. Mol. Hum. Reprod. 7, 1187-1193. doi: 10.1093/ molehr/7.12.1187

Wahid, H. H., Dorian, C. L., Chin, P. Y., Hutchinson, M. R., Rice, K. C., Olson, D. M., et al. (2015). Toll-Like Receptor 4 Is an Essential Upstream Regulator of On-Time Parturition and Perinatal Viability in Mice. Endocrinol 156, 3828-3841. doi: 10.1210/en.2015-1089

Welsh, T., Johnson, M., Yi, L., Tan, H., Rahman, R., Merlino, A., et al. (2012). Estrogen Receptor (ER) Expression and Function in the Pregnant Human Myometrium: Estradiol Via Er $\alpha$ Activates ERK1/2 Signaling in Term Myometrium. J. Endocrinol. 212, 227-238. doi: 10.1530/JOE-11-0358

Wendremaire, M., Hadi, T., Pezze, M., Barrichon, M., Lopez, T., Neiers, F., et al. (2020). Macrophage-Induced Reactive Oxygen Species Promote Myometrial Contraction and Labor-Associated Mechanisms $\dagger$. Biol. Reprod. 102, 13261339. doi: 10.1093/biolre/ioaa032

Wenstrom, K. D., Andrews, W. W., Hauth, J. C., Goldenberg, R. L., DuBard, M. B., and Cliver, S. P. (1998). Elevated Second-Trimester Amniotic Fluid Interleukin-6 Levels Predict Preterm Delivery. Am. J. Obstet Gynecol. 178, 546-550. doi: 10.1016/S0002-9378(98)70436-3

Woods, M., Mitchell, J. A., Wood, E. G., Barker, S., Walcot, N. R., Rees, G. M., et al. (1999). Endothelin-1 is Induced by Cytokines in Human Vascular Smooth Muscle Cells: Evidence for Intracellular Endothelin-Converting Enzyme. Mol. Pharmacol. 55, 902-909.

Word, R. A., Kamm, K. E., and Casey, M. L. (1992). Contractile Effects of Prostaglandins, Oxytocin, and Endothelin-1 in Human Myometrium In Vitro: Refractoriness of Myometrial Tissue of Pregnant Women to Prostaglandins E2 and F2 Alpha. J. Clin. Endocrinol. Metab. 75, 1027-1032. doi: 10.1210 /jcem.75.4.1400867

Wu, W. X., Ma, X. H., Yoshizato, T., Shinozuka, N., and Nathanielsz, P. W. (1999). Differential Expression of Myometrial Oxytocin Receptor and Prostaglandin H Synthase 2, But Not Estrogen Receptor Alpha and Heat Shock Protein 90 Messenger Ribonucleic Acid in the Gravid Horn and Nongravid Horn in Sheep During Betamethasone-Induced Labor. Endocrinology 140, 5712-5718. doi: 10.1210/endo.140.12.7201

Xu, Y., Plazyo, O., Romero, R., Hassan, S. S., and Gomez-Lopez, N. (2015). Isolation of Leukocytes From the Human Maternal-Fetal Interface. J. Vis. Exp. (99), e52863. doi: 10.3791/52863

Xu, Y., Romero, R., Miller, D., Kadam, L., Mial, T. N., Plazyo, O., et al. (2016). An M1-like Macrophage Polarization in Decidual Tissue During Spontaneous Preterm Labor That Is Attenuated by Rosiglitazone Treatment. J. Immunol. 196, 2476-2491. doi: 10.4049/jimmunol.1502055

Yallampalli, C., and Garfield, R. E. (1994). Uterine Contractile Responses to Endothelin-1 and Endothelin Receptors are Elevated During Labor. Biol. Reprod. 51, 640-645. doi: 10.1095/biolreprod51.4.640

Yoshida, K., Jiang, H., Kim, M., Vink, J., Cremers, S., Paik, D., et al. (2014). Quantitative Evaluation of Collagen Crosslinks and Corresponding Tensile Mechanical Properties in Mouse Cervical Tissue During Normal Pregnancy. PloS One 9, e112391. doi: 10.1371/journal.pone.0112391

Yoshimura, K., and Hirsch, E. (2003). Interleukin-6 is Neither Necessary Nor Sufficient for Preterm Labor in a Murine Infection Model. J. Soc. Gynecol. Investig. 10, 423-427. doi: 10.1016/S1071-55760300138-2
Yoshimura, K., and Hirsch, E. (2005). Effect of Stimulation and Antagonism of Interleukin-1 Signaling on Preterm Delivery in Mice. J. Soc. Gynecol. Investig. 12, 533-538. doi: 10.1016/j.jsgi.2005.06.006

You, X., Liu, J., Xu, C., Liu, W., Zhu, X., Li, Y., et al. (2014). CorticotropinReleasing Hormone (CRH) Promotes Inflammation in Human Pregnant Myometrium: The Evidence of CRH Initiating Parturition? J. Clin. Endocrinol. Metab. 99, E199-E208. doi: 10.1210/jc.2013-3366

Young, R. C. (2007). Myocytes, Myometrium, and Uterine Contractions. Ann. N Y Acad. Sci. 1101, 72-84. doi: 10.1196/annals.1389.038

Yuan, M., Jordan, F., McInnes, I. B., Harnett, M. M., and Norman, J. E. (2009). Leukocytes are Primed in Peripheral Blood for Activation During Term and Preterm Labour. Mol. Hum. Reprod. 15, 713-724. doi: 10.1093/molehr/ gap054

Zaragoza, D. B., Wilson, R., Eyster, K., and Olson, D. M. (2004). Cloning and Characterization of the Promoter Region of the Human Prostaglandin F2alpha Receptor Gene. Biochim. Biophys. Acta 1676, 193-202. doi: 10.1016/ j.bbaexp.2003.11.004

Zaragoza, D. B., Wilson, R. R., Mitchell, B. F., and Olson, D. M. (2006). The Interleukin 1beta-Induced Expression of Human Prostaglandin F2alpha Receptor Messenger RNA in Human Myometrial-Derived ULTR Cells Requires the Transcription Factor, Nfkappab. Biol. Reprod. 75, 697-704. doi: 10.1095/biolreprod.106.053439

Zhang, J., Shynlova, O., Sabra, S., Bang, A., Briollais, L., and Lye, S. J. (2017). Immunophenotyping and Activation Status of Maternal Peripheral Blood Leukocytes During Pregnancy and Labour, Both Term and Preterm. J. Cell Mol. Med. 21, 2386-2402. doi: 10.1111/jcmm.13160

Zhao, Y., Koga, K., Osuga, Y., Izumi, G., Takamura, M., Harada, M., et al. (2013). Cyclic Stretch Augments Production of Neutrophil Chemokines and Matrix Metalloproteinases-1 (MMP-1) From Human Decidual Cells, and the Production Was Reduced by Progesterone. Am. J. Reprod. Immunol. 69, 454-462. doi: 10.1111/aji.12092

Conflict of Interest: DO and SC are founders of Maternica Therapeutics, Inc.

The remaining authors declare that the research was conducted in the absence of any commercial or financial relationships that could be construed as a potential conflict of interest.

Publisher's Note: All claims expressed in this article are solely those of the authors and do not necessarily represent those of their affiliated organizations, or those of the publisher, the editors and the reviewers. Any product that may be evaluated in this article, or claim that may be made by its manufacturer, is not guaranteed or endorsed by the publisher.

Copyright (๑) 2021 Leimert, Xu, Princ, Chemtob and Olson. This is an open-access article distributed under the terms of the Creative Commons Attribution License (CC BY). The use, distribution or reproduction in other forums is permitted, provided the original author(s) and the copyright owner(s) are credited and that the original publication in this journal is cited, in accordance with accepted academic practice. No use, distribution or reproduction is permitted which does not comply with these terms. 